\title{
Biometry of detached Emiliania huxleyi coccoliths along the Patagonian Shelf
}

\author{
Alex J. Poulton ${ }^{1, *}$, Jeremy R. Young ${ }^{2}$, Nicholas R. Bates ${ }^{3}$, William M. Balch ${ }^{4}$ \\ ${ }^{1}$ National Oceanography Centre, Waterfront Campus, Southampton SO14 3ZH, UK \\ ${ }^{2}$ University College London, Gower Street, London WC1E 6BT, UK \\ ${ }^{3}$ Bermuda Institute of Ocean Sciences, St. George's GE 01, Bermuda
}

${ }^{4}$ Bigelow Laboratory for Ocean Sciences, 180 McKown Point Road, PO Box 475, West Boothbay Harbour, Maine 04575-0475, USA

ABSTRACT: The biometry (morphology, size) of coccoliths of the coccolithophorid Emiliania huxleyi has implications for their calcite content and cellular rates of calcification. We investigated the biometry of detached coccoliths of E. huxleyi in surface waters during the December 2008 'Coccolithophores of the Patagonian Shelf (COPAS'08)' expedition. Two morphotypes of E. huxleyi were abundant along the shelf, although with different distributions: Morphotype A dominated waters on the shelf and at the northern end of the shelf, while Morphotype B/C dominated offshore and within the main coccolithophore bloom. The 2 morphotypes had opposite relationships to environmental variables along the shelf: Morphotype B/C was abundant in cold $\left(<10^{\circ} \mathrm{C}\right)$, nutrient-rich $\left(>10 \mu \mathrm{mol}\right.$ nitrate $\left.\mathrm{kg}^{-1}\right)$ waters with calcite saturation states of $\sim 3.5$, whereas Morphotype A was abundant in warm $\left(>10^{\circ} \mathrm{C}\right)$, nutrientpoor ( 0.1 to $10 \mu \mathrm{mol}$ nitrate $\mathrm{kg}^{-1}$ ) waters with higher (>4.5) calcite saturation states. These findings support previous suggestions that E. huxleyi morphotypes are distinct ecotypes. Furthermore, we suggest that Morphotype B/C is a Southern Ocean ecotype. Measurements of coccolith distal shield length (total range: 1.8 to $4.4 \mu \mathrm{m}$ ) indicated considerable physiological and/or phenotypic variability along the shelf and within each morphotype. Conversion of distal shield length into estimates of coccolith calcite showed that the E. huxleyi population was producing coccoliths with low median calcite quotas (overall average $\pm \mathrm{SD}, 0.015 \pm 0.006 \mathrm{pmol} \mathrm{C}$ ) relative to other studies of field populations.

KEY WORDS: Emiliania huxleyi - Calcification · Patagonian Shelf . Coccoliths - Morphotypes · COPAS'08

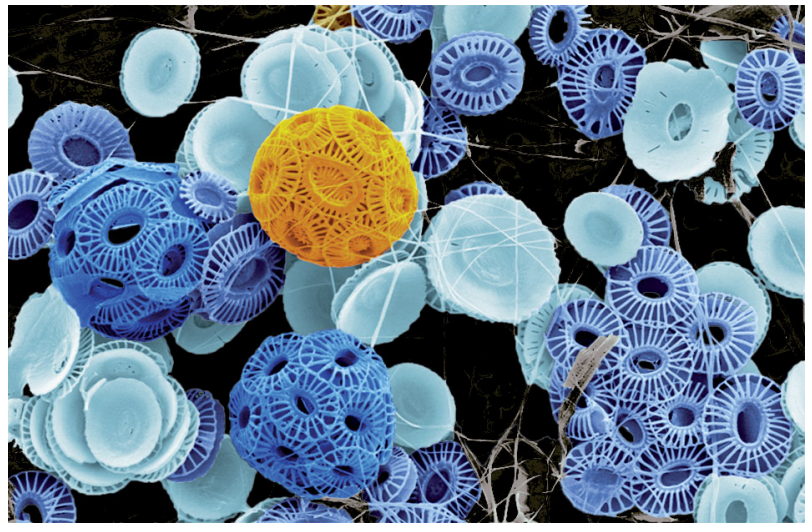

SEM of coccoliths and coccospheres of Emiliania huxleyi Morphotypes A (orange) and B/C (blue), which have different coccolith calcite contents.

Image: Helen Smith (NOC)

\section{INTRODUCTION}

The ubiquitous coccolithophorid Emiliania huxleyi (Lohmann) Hay et Mohler is one of the major oceanic calcium carbonate $\left(\mathrm{CaCO}_{3}\right)$ producers and exporters in the modern ocean, with an abundant fossil record over the last 0.3 million yr (Baumann 2004). Cells of E. huxleyi are composed of an inner organic-rich cell covered by an exoskeleton of interlocking calcite scales termed coccoliths (Fig. 1A). These coccoliths are produced within intracellular vesicles and excreted to the outer surface of the cell to form the coccosphere (Fig. 1B,C). The rate of formation of 

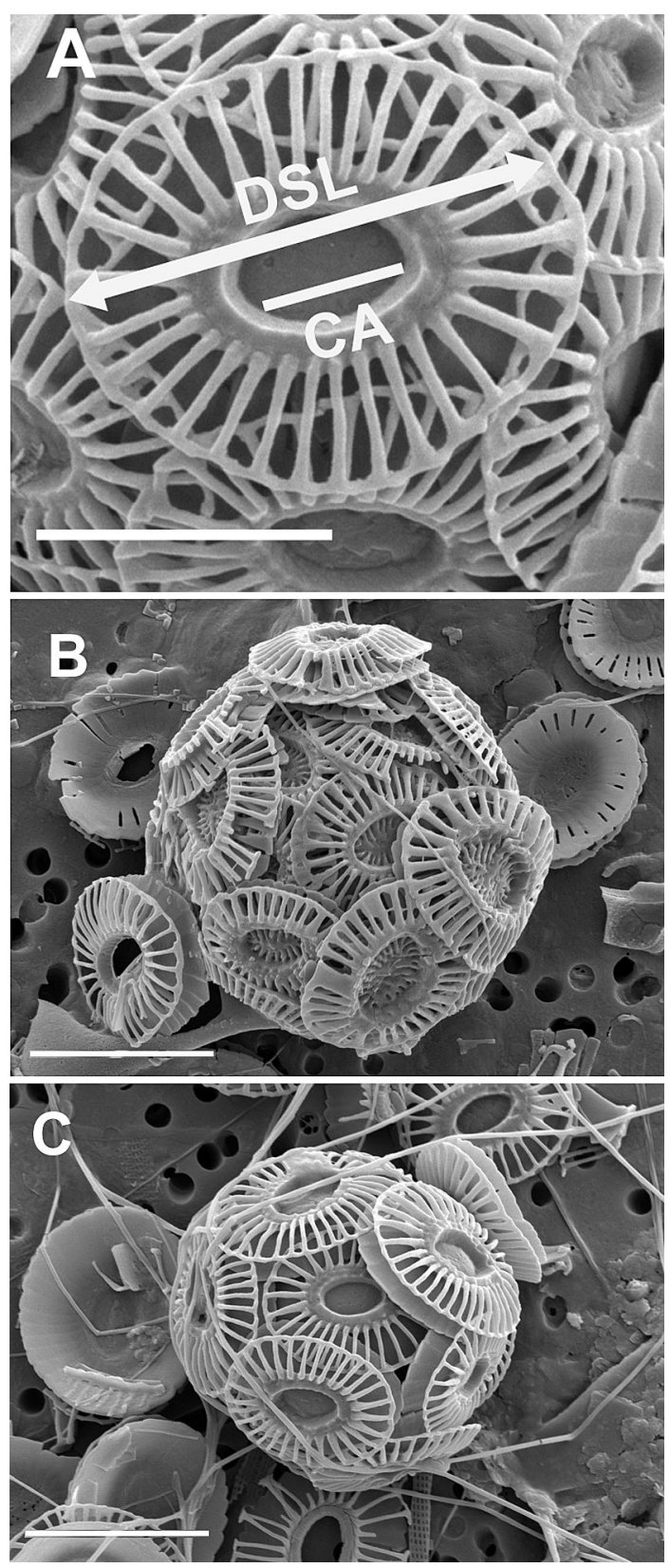

Fig. 1. Emiliania huxleyi. SEM images of (A) a detached coccolith with distal shield length (DSL) and central area (CA) indicated, (B) coccospheres of Morphotype A, and (C) of Morphotype B/C. White scale bars in Panels A to C: $2 \mu \mathrm{m}$

coccoliths (i.e. rate of calcification) and the rate of loss of coccoliths from the coccosphere (coccolith detachment) are both linked to nutrient and light availability (Paasche 2001, Zondervan 2007, Müller et al. 2008), with sharp increases in coccolith detachment rates during nutrient and light stress (Balch et al. 1993, Paasche 2001). In healthy, nutrient- replete E. huxleyi cells, around 12 to 15 coccoliths form the coccosphere, with this number rising with nutrient depletion so that the cells become covered in multiple layers of coccoliths (Balch et al. 1993).

Currently, several distinct morphotypes of Emiliania huxleyi are recognised (e.g. Young et al. 2003), with additional morphological variation occurring within each coccolith morphotype (Young 1994, Batvik et al. 1997, Paasche 1998, 2001, Hagino et al. 2005, Triantaphyllou et al. 2010). The common morphotypes are referred to as A (Fig. 1B), B, C and R (e.g. Young et al. 2003) or as distinct E. huxleyi varieties (var. huxleyi, var. pujosae, var. kleijniae; Medlin et al. 1996). E. huxleyi coccoliths are attributed to the different morphotypes by their size, shape in profile and central area characteristics (Table 1; see also Young et al. 2003). A fifth morphotype, B/C (Fig. 1C) is observed in the southern hemisphere (Cubillos et al. 2007, Holligan et al. 2010, Cook et al. 2011) and subpolar waters (Hagino et al. 2005). It is similar to the $\mathrm{B}$ and $\mathrm{C}$ morphotypes, but intermediate in size between them (Table 1; see also Young et al. 2003, Hagino et al. 2005). Recently, Cook et al. (2011) proposed the $\mathrm{B} / \mathrm{C}$ morphotype as the variety aurorae after finding significant genetic and photosynthetic pigment differences between cultures of Morphotypes B/C and A.

Culture experiments have shown that uni-algal strains do not change morphotype but do show subtler variation in aspects of coccolith morphology, especially size and degree of calcification (Young \& Westbroek 1991). This morphological variation has been linked to environmental factors, such as salinity (e.g. Paasche et al. 1996, Bollmann et al. 2009), temperature (Watabe \& Wilbur 1966), temperature and phosphate (Satoh et al. 2009), or nutrient availability (e.g. Young \& Westbroek 1991, Young 1994, Paasche 1998). However, linking these observations to field populations is severely hampered by several factors, including a requirement to know which morphotype(s) is being studied, and there is considerable intra-strain variability in physiological responses to environmental drivers (e.g. Langer et al. 2009). Natural populations of Emiliania huxleyi are often a mixture of morphotypes; hence, changes in, for example, average coccolith size between populations may result from changes within a morphotype, or from changes in the relative abundance of the different morphotypes. Thus, examining changes in morphotype abundance in the context of hydrographic gradients is a priority for understanding the factors that control E. huxleyi distribution in the global ocean. 
Table 1. Emiliania huxleyi. Morphotype coccolith characteristics, including distal shield length (DSL), central area (CA) morphology, volume $\left(k_{\mathrm{s}}\right)$ and calcite content per coccolith. The shape constant $\left(k_{\mathrm{s}}\right)$ values for coccoliths of Morphotypes A and B were taken from Young \& Ziveri (2000). The $k_{\mathrm{s}}$ value for Morphotype B/C was taken from Young (unpubl. data). Information summarised from Young et al. (2003), see also Hagino et al. (2005). DS: distal shield; PS: proximate shield

\begin{tabular}{|c|c|c|c|c|}
\hline Morphotype & $\begin{array}{l}\text { DSL } \\
(\mu \mathrm{m})\end{array}$ & CA morphology & $k_{\mathrm{s}}$ & $\begin{array}{l}\text { Calcite content } \\
\text { (pmol C) }\end{array}$ \\
\hline A & $3-4$ & DSL elements robust, CA elements curved, DS larger than PS & 0.02 & $0.015-0.035$ \\
\hline B & $3.5-5$ & DSL elements delicate, CA elements irregular, PS often larger than DS & 0.02 & $0.023-0.068$ \\
\hline $\mathrm{B} / \mathrm{C}$ & $2-4$ & DSL elements delicate, CA open or thin plate, PS similar to DS & 0.015 & $0.011-0.026$ \\
\hline
\end{tabular}

Considerable variability also exists in the calcite content of coccoliths of different coccolithophore species (Young \& Ziveri 2000), which has important implications for their relative contribution to deepsea $\mathrm{CaCO}_{3}$ fluxes (Baumann 2004, Ziveri et al. 2007). Such differences in size will also affect coccolith optical properties (Gordon \& Du 2001, Gordon et al. 2009). The morphotypes of Emiliania huxleyi also have different coccolith quotas (Young \& Ziveri 2000), although how these may equate to differences in contributions to pelagic calcite production or export is unclear. There are currently 2 main approaches to analysing coccolith mass variations. The cross-polarised light-microscopy-based technique of Beaufort (2005) is based on the fact that at low retardation values (i.e. first-order greys) the brightness of a crystal in a given orientation is a near-linear function of its thickness and that coccoliths, since they are micron-sized objects formed of calcite, produce retardations of this magnitude (Young 1993). The advantage of this technique is that it can produce measurements of the mass of individual coccoliths and, as implemented by Beaufort et al. (2008), it can produce automated measurements of both mass and length of 100 s of coccoliths in a relatively short time. Disadvantages of the method include that it cannot differentiate morphotypes and that there are substantial errors in the size and mass estimates for each specimen.

The alternative Scanning Electron Microscopy (SEM)-based method makes accurate morphometric measurements on electron micrographs. The advantage of this is that specimens can be identified to morphotype level and that there are relatively small errors in the measurements ( 0.1 to $0.2 \mu \mathrm{m})$. However, it is not possible to measure coccolith thickness directly, and, hence, it is usually assumed that thickness co-varies with length. This method was described in detail by Young \& Ziveri (2000), who suggested that, for a given coccolith species or morphotype, the mass of coccolith calcite can be estimated as:
Coccolith calcite $($ pmol C $)=2.7 \times k_{\mathrm{s}} \times L^{3} / 100$

where 2.7 is the density of $\mathrm{CaCO}_{3}\left(\mathrm{pg} \mu \mathrm{m}^{3}\right), k_{\mathrm{s}}$ is a shape constant for the different coccolith morphologies, $L$ is a characteristic length, in microns, usually the distal shield length (DSL; see Fig. 2) (Young \& Ziveri 2000) and 100 is the molecular weight of calcite. Coccolith shape constants $\left(k_{\mathrm{s}}\right)$ are derived from cross-section reconstructions incorporating a range of observations and microscopic measurements with $\mathrm{a} \pm 20 \%$ error associated with $k_{\mathrm{s}}$ calculation (Young \& Ziveri 2000). The SEM method is most appropriate when examining how morphotypes influence calcite production and standing stocks, as in the case in the present study.

For Emiliania huxleyi, a wide range of calcite content values has been proposed from both, laboratory and field studies (e.g. Holligan et al. 1993, see references in Young \& Ziveri 2000, Beaufort 2005, Holligan et al. 2010). Taking the range of coccolith dimensions for each morphotype of E. huxleyi (from Young et al. 2003) and applying Eq. (1) gives a range of estimates for coccolith calcite content for the different morphotypes (Table 1). Importantly, the rate of individual coccolith production by an E. huxleyi cell will be determined by both its cellular calcification rate and its coccolith calcite content: a cell calcifying at a rate of $0.3 \mathrm{pmol} \mathrm{C} \mathrm{d}{ }^{-1}$ (average value from Poulton et al. 2010 in the Iceland Basin) would be able to produce 12 coccoliths $\mathrm{d}^{-1}$ of Morphotype A $(0.8$ coccoliths $\mathrm{h}^{-1}$, assuming a $16 \mathrm{~h}$ day) or 16 coccoliths $\mathrm{d}^{-1}$ of Morphotype B/C $\left(1\right.$ coccolith $\left.\mathrm{h}^{-1}\right)$, assuming median calcite contents from the values in Table 1. Clearly, coccolith calcite quotas may set the physiological boundaries for cellular calcification rates. However, few field studies have examined either cellular calcification rates or coccolith calcite content in the context of environmental factors for naturally occurring E. huxleyi populations.

Emiliania huxleyi forms large-scale blooms in several regions of the world ocean (Iglesias-Rodriguez et 
al. 2002a), among which the Patagonian Shelf is one of the most prominent and largest areas of regular blooms (Tyrrell \& Merico 2004, Signorini et al. 2006, Garcia et al. 2011). The Patagonian Shelf is a complex hydrographic regime, where warm low-nutrient subtropical waters from the north mix with cold highnutrient waters from the Southern Ocean (Painter et al. 2010, Garcia et al. 2011). Hence, the Patagonian Shelf is an ideal environment to examine variability in E. huxleyi morphotype abundance and coccolith calcite content in the context of hydrographic variability. Samples for examination of E. huxleyi biometry were collected as part of the December 2008 United States-led multidisciplinary 'Coccolithophores of the Patagonian Shelf' (COPAS'08) expedition. During the COPAS'08 cruise a large bloom of E. huxleyi (>10 $\times 10^{3}$ coccoliths $\mathrm{ml}^{-1}$ ) was present along the southern portion of the shelf (Fig. 2, Table 2), with waters elevated in calcite being carried north via the northern flow of the Falklands (Malvinas) current (Painter al. 2010). The bloom developed from north to

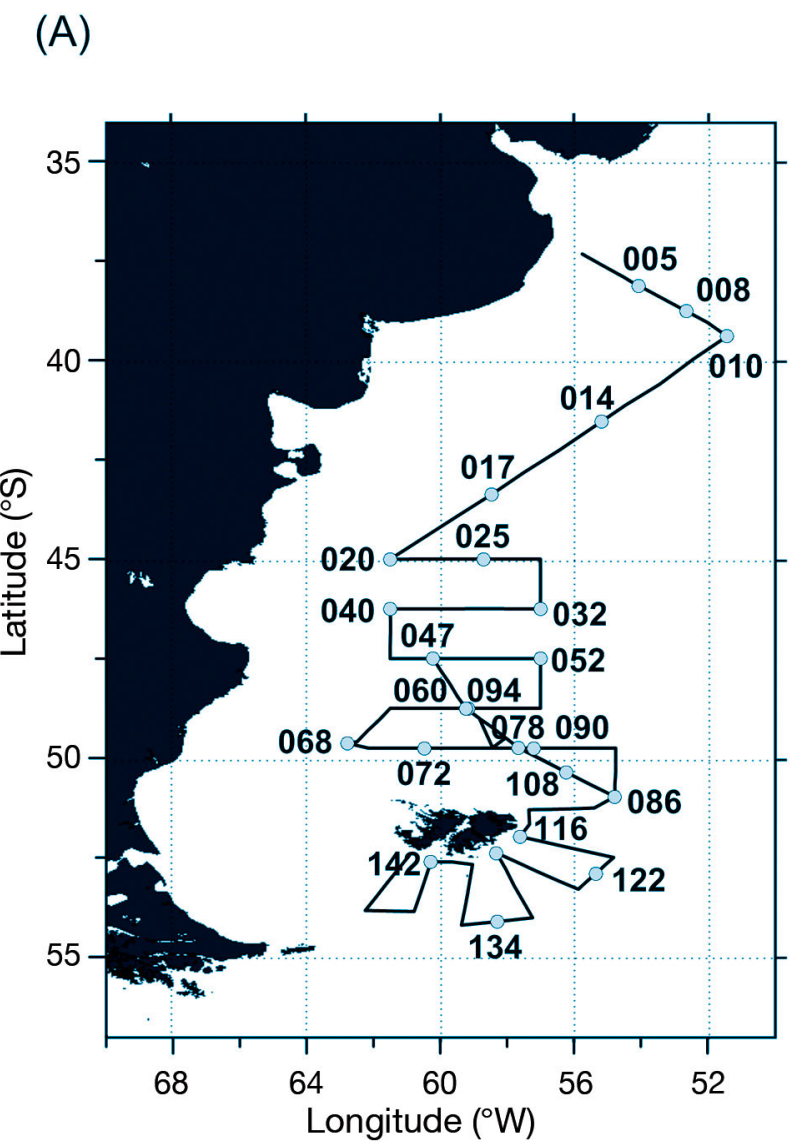

south, with the peak of the bloom being about $3 \mathrm{wk}$ earlier to the north of the Falklands Plateau than to the south (Painter et al. 2010).

\section{MATERIALS AND METHODS}

\section{Sampling}

Sampling was carried out onboard the RV 'Roger Revelle' (Cruise Knox22RR) which sailed from Montevideo, Uruguay (4 December 2008) to Punta Arenas, Chile (2 January 2009). The COPAS'08 cruise sampled 152 conductivity-temperature-depth (CTD) stations along the Patagonian Shelf, with samples for the present study being collected from 25 pre-dawn productivity (00:30 to 08:00 h GMT) CTD deployments (Fig. 2A). Surface water samples (1 to $9 \mathrm{~m}$ depth; $\sim 50 \%$ incidental irradiance) were collected during deployment of a Seabird SBE 911 CTD equipped with $24 \times 201$ Go-Flow Niskin bottles.

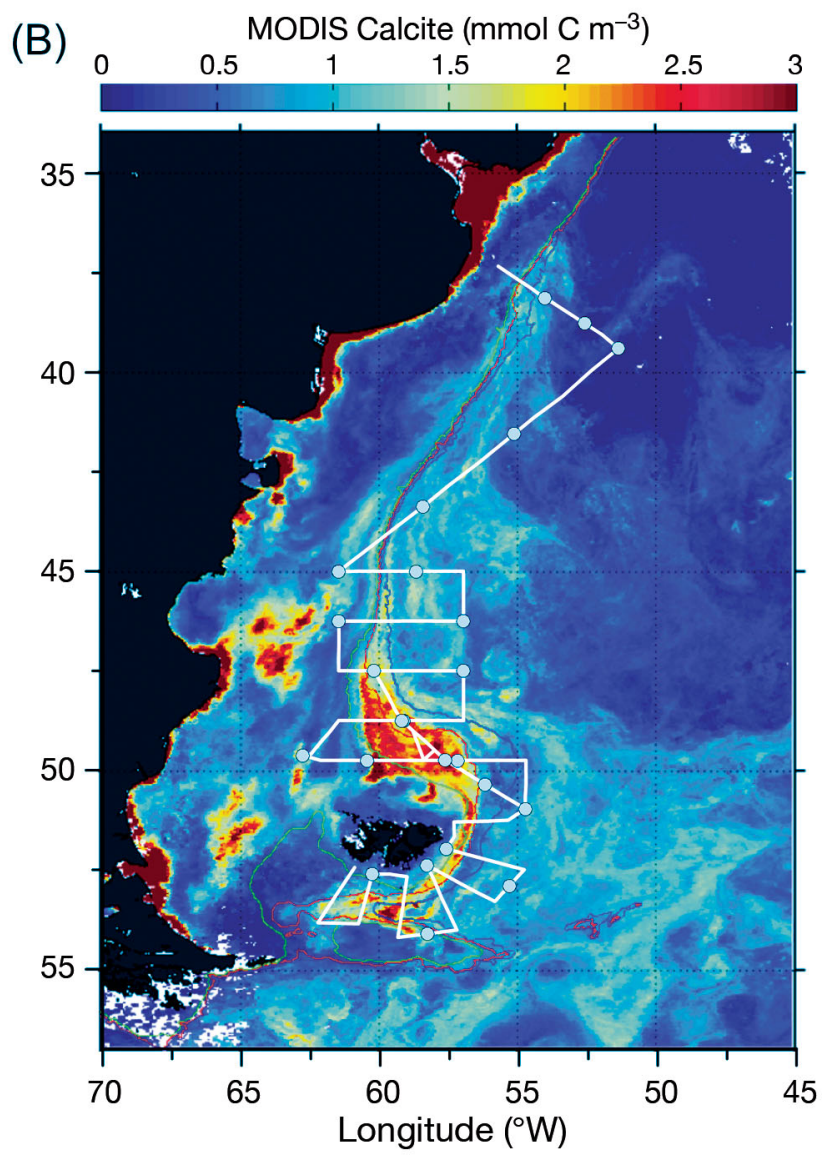

Fig. 2. (A) Cruise track and sampling stations; (B) the same superimposed on a monthly composite (December 2008) of MODISAqua ocean color measurements, showing the merged 2-band/3-band calcite product. Color bar shown at top for calcite concentration. Two sets of sampling stations were at or near the same position: Stns 060, 094 and 102 (not shown for clarity); and Stns 078 and 090. Stn 128, after Stn 122, is close to the Falkland Islands and not labelled for clarity 
Table 2. Summary of sampling stations and characteristics of the coccolithophore community from the COPAS'08 cruise. Dominant species is the species which represents $>30 \%$ of total coccosphere numbers alone. Hydrographic provinces are classified based after Painter et al. (2010), using abbreviations for the major provinces given in Fig. 4. Station classification relative to 'bloom' waters is based on threshold values for coccolith abundances $-\mathrm{N}$ : non-bloom, $<1 \times 10^{3}$ coccoliths ml $^{-1}$; O: outer bloom, $1 \times 10^{3}$ to $10 \times 10^{3}$ coccoliths $\mathrm{ml}^{-1}$; : central bloom, $>10 \times 10^{3}$ coccoliths $\mathrm{ml}^{-1}$

\begin{tabular}{|c|c|c|c|c|c|c|c|c|}
\hline Station & $\begin{array}{l}\text { Latitude } \\
\left({ }^{\circ} \mathrm{S}\right)\end{array}$ & $\begin{array}{l}\text { Longitude } \\
\left({ }^{\circ} \mathrm{W}\right)\end{array}$ & $\begin{array}{l}\text { Depth } \\
\text { (m) }\end{array}$ & $\begin{array}{l}\text { Coccosphere } \\
\text { abundance } \\
\left(\times 10^{3} \mathrm{ml}^{-1}\right)\end{array}$ & $\begin{array}{c}\text { Emiliania huxleyi } \\
\text { coccoliths } \\
\left(\times 10^{3} \mathrm{ml}^{-1}\right)\end{array}$ & $\begin{array}{l}\text { Dominant } \\
\text { species }\end{array}$ & $\begin{array}{l}\text { Hydrographic } \\
\text { province }\end{array}$ & $\begin{array}{l}\text { Relative } \\
\text { to 'bloom' } \\
\text { waters }\end{array}$ \\
\hline 005 & 38.07 & 54.03 & 1 & 0.01 & 0.03 & Syracosphaera delicata & SW & $\mathrm{N}$ \\
\hline 008 & 38.46 & 52.38 & 9 & 0.06 & 0.4 & Diverse & $\mathrm{BC}$ & $\mathrm{N}$ \\
\hline 010 & 39.23 & 51.24 & 1 & 0.13 & 0.2 & Umbellosphaera tenuis & $\mathrm{T}$ & $\mathrm{N}$ \\
\hline 014 & 41.32 & 55.10 & 1 & 0.09 & 0.2 & Syracosphaera marginaporata & $\mathrm{T}$ & $\mathrm{N}$ \\
\hline 017 & 43.22 & 58.27 & 1 & 0.20 & 4.0 & Emiliania huxleyi & NFC & $\mathrm{O}$ \\
\hline 020 & 45.00 & 61.29 & 3 & 0.05 & 1.1 & S. marginaporata & SW & $\mathrm{N}$ \\
\hline 025 & 45.00 & 58.43 & 1 & 0.41 & 13.0 & E. huxleyi & NFC & $\mathrm{C}$ \\
\hline 032 & 46.15 & 57.00 & 1 & 0.19 & 2.3 & E. huxleyi, diverse & $\mathrm{NFC}$ & $\mathrm{O}$ \\
\hline 040 & 46.15 & 61.29 & 3 & 0.01 & 0.7 & Diverse & ASW & $\mathrm{N}$ \\
\hline 047 & 47.29 & 60.13 & 1 & 0.45 & 23.4 & E. huxleyi & ASW & $\mathrm{C}$ \\
\hline 052 & 47.30 & 57.00 & 1 & 0.18 & 1.8 & E. huxleyi, diverse & NFC & $\mathrm{O}$ \\
\hline 060 & 48.45 & 59.09 & 3 & 0.80 & 14.8 & E. huxleyi & NFC & $\mathrm{C}$ \\
\hline 068 & 49.38 & 62.47 & 1 & 0.79 & 19.7 & E. huxleyi & SW & $\mathrm{C}$ \\
\hline 072 & 49.45 & 60.28 & 2 & 0.11 & 2.8 & E. huxleyi & ASW & $\mathrm{O}$ \\
\hline 078 & 49.45 & 57.12 & 1 & 3.06 & 39.8 & E. huxleyi & ASW & $\mathrm{C}$ \\
\hline 086 & 50.58 & 54.46 & 1 & 0.13 & 7.5 & E. huxleyi & SFC & $\mathrm{O}$ \\
\hline 090 & 49.45 & 57.39 & 1 & 1.38 & 33.9 & E. huxleyi & ASW & $\mathrm{C}$ \\
\hline 094 & 48.45 & 59.09 & 3 & 0.36 & 19.4 & E. huxleyi & NFC & $\mathrm{C}$ \\
\hline 102 & 48.45 & 59.14 & 3 & 0.32 & 14.8 & E. huxleyi & NFC & $\mathrm{C}$ \\
\hline 108 & 50.22 & 56.13 & 4 & 0.38 & 23.1 & E. huxleyi & NFC & $\mathrm{C}$ \\
\hline 116 & 51.58 & 57.37 & 3 & 0.48 & 14.5 & E. huxleyi & ASW & $\mathrm{C}$ \\
\hline 122 & 55.24 & 55.20 & 3 & 0.16 & 8.5 & E. huxleyi & $\mathrm{SFC}$ & $\mathrm{O}$ \\
\hline 128 & 52.23 & 58.19 & 3 & 0.17 & 12.5 & E. huxleyi & ASW & $\mathrm{C}$ \\
\hline 134 & 54.06 & 58.18 & 1 & 0.58 & 20.6 & E. huxleyi & $\mathrm{SFC}$ & $\mathrm{C}$ \\
\hline 142 & 52.36 & 60.17 & 2 & 0.25 & 6.9 & E. huxleyi & ASW & $\mathrm{O}$ \\
\hline
\end{tabular}

Water samples $(0.2$ to 1 l) were collected in 21 blacked-out polycarbonate bottles and filtered through $25 \mathrm{~mm}$ diameter $0.2 \mu \mathrm{m}$ polycarbonate filters under low vacuum. Filters were oven dried $\left(40\right.$ to $50^{\circ} \mathrm{C}, 6$ to $8 \mathrm{~h}$ ) and stored on petri-slides until SEM analysis.

\section{SEM analysis}

A small portion $(\sim 0.5 \times 0.5 \mathrm{~cm})$ of the filter was cut from the centre, mounted on an aluminium stub and coated in $\sim 2 \mathrm{~nm}$ gold. A Leo 1450VP SEM (Carl Zeiss) with SmartSEM (V5.1) software was then used to automatically capture images of consecutive fields of view (FOV) from a $15 \times 15$ FOV grid at a magnification of $\times 5000$, providing 225 images for analysis of the abundance of coccolithophores and detached coccoliths, and coccolith morphometrics. Either all 225 FOV or 300 coccospheres and 300 coccoliths (whichever was arrived at first) were counted per filter, with a minimum of $30 \mathrm{FOV}$ for coccospheres and 10 FOV for detached coccoliths when these were abundant. The number of FOVs counted was used to calculate the area of the filter covered (the size of 1 FOV was $4.054 \times 10^{-3} \mathrm{~mm}^{2}$ ). Coccospheres and detached coccoliths were identified to species and/or morphotype following Young et al. (2003), and the abundance $\left(\mathrm{ml}^{-1}\right)$ was calculated as $C \times(F / A) / V$, where $C$ is total number counted, $A$ is the area investigated $\left(\mathrm{mm}^{2}\right), F$ is the total filter area $\left(\mathrm{mm}^{2}\right)$ and $V$ is the volume filtered $(\mathrm{ml})$.

\section{Coccolith measurements}

Detached coccoliths ( $\mathrm{n}=50$ per sample) of Emiliania huxleyi in distal shield view were classified into morphotypes based on distal shield length (DSL; Fig. 1A) and central area (CA) morphology in accordance with the criteria found in Young et al. (2003) and which are summarised in Table 1. DSL was measured on the SEM images using the image processing software Image-J (http://rsbweb.nih.gov/ij/), after scale calibration using a $10 \mu \mathrm{m}$ scale bar pre-set on each SEM image. DSL was converted to coccolith calcite content using Eq. (1) in the present study (Young \& Ziveri 
2000). Potential errors associated with this method of estimating coccolith calcite from DSL measurements are associated with the constant value of $k_{\mathrm{s}}$, the error of which is estimated to be $\pm 20 \%$, and potential SEM measurement errors, which we assumed to be $<5 \%$. This total error of $\pm 30 \%$ compares well with other techniques for weighing coccoliths, for example, variability in the orientation of E. huxleyi coccoliths can cause errors up to $\sim 28 \%$ in estimates based on birefringence (Beaufort 2005).

\section{Seawater carbonate chemistry}

Samples for dissolved inorganic carbon (DIC) and total alkalinity (TA) were collected from each hydrocast station and also opportunistically from the underway seawater supply (surface water from an intake at depth of $\sim 5 \mathrm{~m}$ ). Both hydrocast and underway surface samples were sampled into $\sim 300 \mathrm{ml}$ Pyrex bottles, poisoned with $\mathrm{HgCl}_{2}$, sealed, and returned to the Bermuda Institute of Ocean Sciences (BIOS) for analysis. DIC sample analyses were made using coulometric methods (Bates et al. 1996, Dickson et al. 2007) and a VINDTA DIC system. TA sample analyses were made using potentiometric methods (Bates et al. 1996, Dickson et al. 2007) and a VINDTA TA system. Certified reference materials (CRMs) were routinely used for both DIC and TA analyses, with the precision and accuracy of both measurements $<0.1 \%$ or $\sim 2 \mu \mathrm{mol} \mathrm{kg}{ }^{-1}$. Calcite saturation state $\left(\Omega_{\text {calcite }}\right), \mathrm{pH}$ and $\mathrm{pCO}_{2}$ were calculated from DIC, TA, temperature, salinity, nutrient and pressure data using the CO2Sys program (Pierrot et al. 2006) and the pK values by Mehrbach et al. (1973) as refit by Dickson \& Millero (1987). The error associated with these calculations was typically $\pm 0.01 \mathrm{pH}$ units and $10 \mu \mathrm{mol} \mathrm{kg}{ }^{-1}$ for $\mathrm{pH}$ and $\mathrm{pCO}_{2}$, respectively.

\section{Ancillary variables}

Surface temperature and salinity were taken directly from the CTD data for the sampling depth. Surface macronutrient (nitrate and phosphate) concentrations were determined using an auto-analyser following standard protocols (Grasshoff et al. 1983). Mixed-layer depths (MLD) were calculated from a temperature threshold difference of $0.5^{\circ} \mathrm{C}$ relative to surface data (Painter et al. 2010). Daily incidental irradiance $\left(\operatorname{Ed}_{[0-]}\right)$, in terms of photosynthetically active radiation (PAR), was integrated from dawn to dusk (mol PAR $\mathrm{m}^{-2} \mathrm{~d}^{-1}$ ) from the PAR sensor on the
RV 'Roger Revelle'. Problems with the calibration of the PAR sensor aboard resulted in the ship's measurements being calibrated against satellite-derived values (MODIS, average of 9 pixels, $\sim 27 \times 27 \mathrm{~km}$, with individual sampling stations closest to the central pixel), so that the relationship between the ship's and satellite's PAR values had a slope of 1 (i.e. using the equation: $\mathrm{PAR}_{\text {ship }}=\mathrm{PAR}_{\text {satellite }} \times 0.569+8.78, \mathrm{r}=$ $0.77, \mathrm{p}<0.001, \mathrm{n}=19)$. The vertical diffuse attenuation coefficient of PAR $\left(K_{\mathrm{d}}\right)$ in the water column was calculated for pre-dawn CTD stations following the methodology of Balch et al. (2011), where a relationship between beam transmittance and $K_{\mathrm{d}}$ is established from midday CTD casts and used to predict $K_{\mathrm{d}}$ during pre-dawn casts. The average mixed-layer PAR irradiance $\left(\overline{\mathrm{E}}_{[\mathrm{ML}]}\right)$ was calculated following Kirk (1994) using a combination of $\operatorname{Ed}_{[0-]}, K_{\mathrm{d}}$ and the mixed-layer depth (MLD) as:

$\overline{\operatorname{E}} \mathrm{d}_{[\mathrm{ML}]}\left(\mathrm{mol}\right.$ PAR m$\left.{ }^{-2} \mathrm{~d}^{-1}\right)=\operatorname{Ed}_{[0-]} \times\left(1-\exp ^{-\mathrm{Kz}}\right) / \mathrm{Kz}$

where $\mathrm{Kz}=K_{\mathrm{d}} \times \mathrm{MLD}$. The variable $\overline{\mathrm{E}} \mathrm{d}_{[\mathrm{ML}]}$ describes the mean light experienced by a particle being mixed from the surface to the base of the mixed layer. The euphotic zone depth was defined as the depth where irradiance was $1 \%$ of near-surface values, with an optical depth of 4.6 (Kirk 1994).

\section{Statistical analysis}

For the statistical analysis of environmental variables, Stn 005 was removed due to $<50$ detached coccoliths being observed, and Stn 025 was removed due to a lack of seawater carbonate chemistry data. Principal component analysis (PCA) of normalised environmental variables was performed using EPRIMER (V6.1.1), and Pearson product-moment correlations (r) were performed in Excel 2007 to describe the correlations between ecological and environmental variables.

\section{RESULTS}

\section{General oceanography}

Sea-surface temperature (SST) decreased from $17-18^{\circ} \mathrm{C}$ at the first 3 stations to $10-15^{\circ} \mathrm{C}$ for stations down to Stn 078 , with temperatures generally $<10^{\circ} \mathrm{C}$ for stations south of Stn 078 (Fig. 3A). Sea-surface salinity was relatively high at the first few stations and decreased to $<34.5$ from Stn 017 onwards, with Stns 020 and 068 having low salinities of $<33.5$ 
(A)

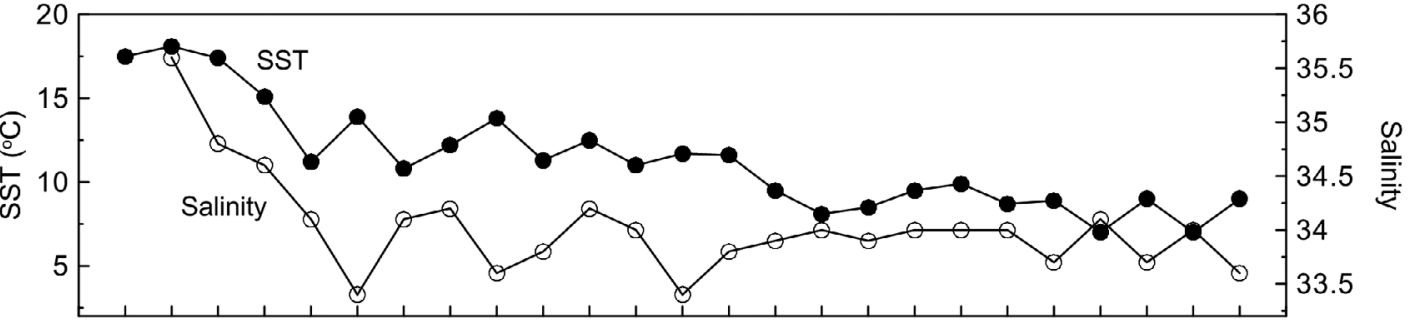

(B)

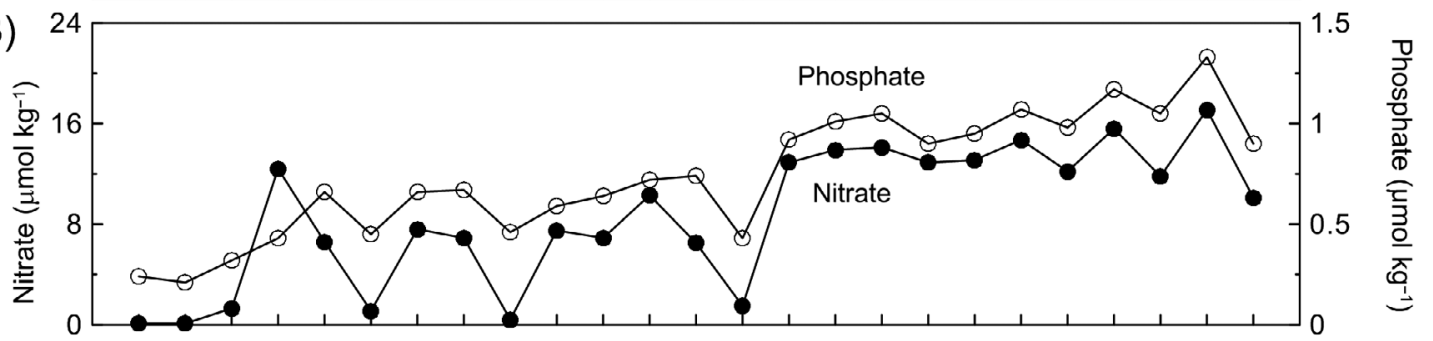

(C)

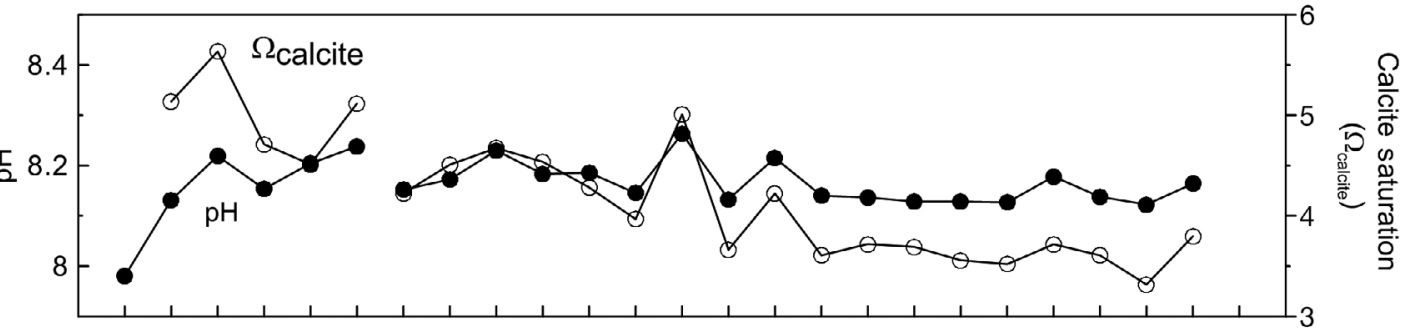

(D)

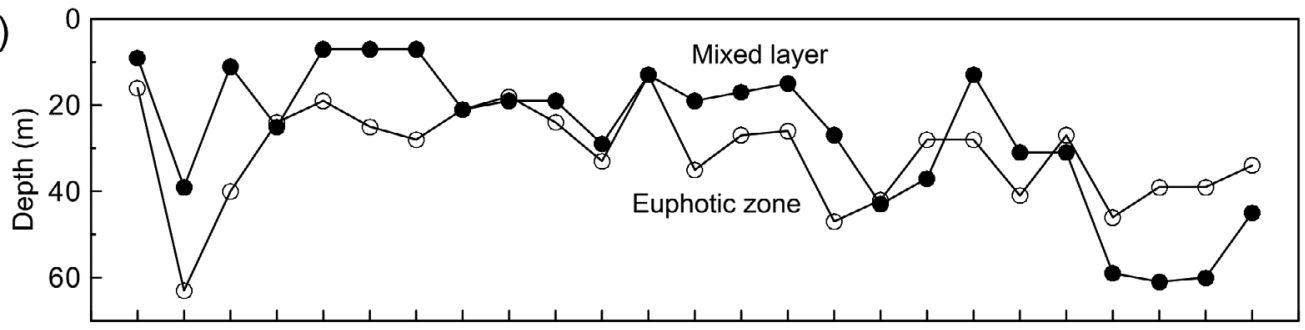

(E)

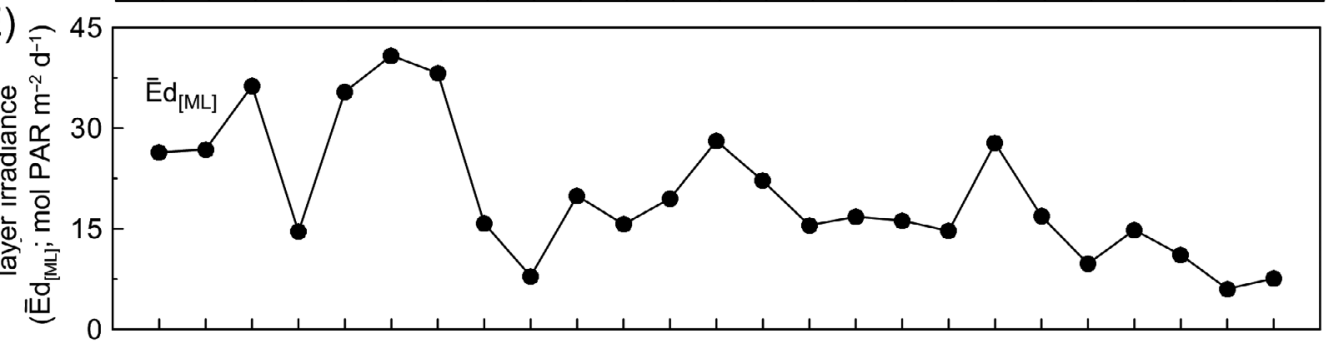

(F)

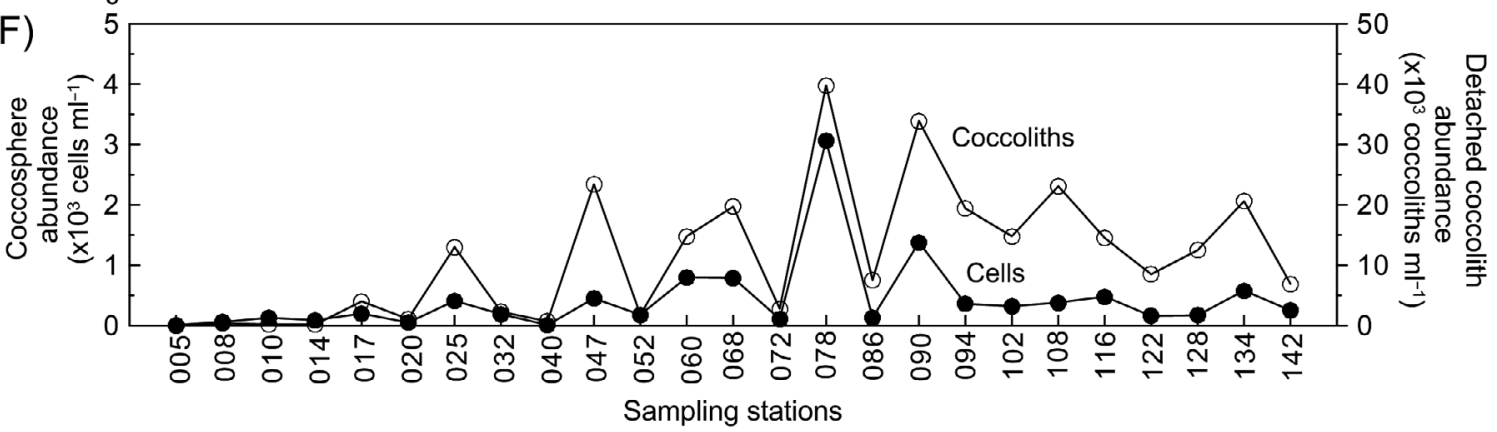

Fig. 3. Surface hydrography and Emiliania huxleyi abundance. (A) Sea-surface temperature (SST) and salinity, (B) surface nitrate and phosphate concentrations, (C) surface water $\mathrm{pH}$ and calcite saturation state $\left(\Omega_{\text {calcite) }}\right)$ (D) mixed-layer and euphotic zone depths, $(\mathrm{E})$ average mixed-layer irradiance $\left(\overline{\mathrm{E}} \mathrm{d}_{[\mathrm{ML}]}\right)$, and $(\mathrm{F})$ abundance of $E$. huxleyi coccospheres (cells) and detached coccoliths (coccoliths) 


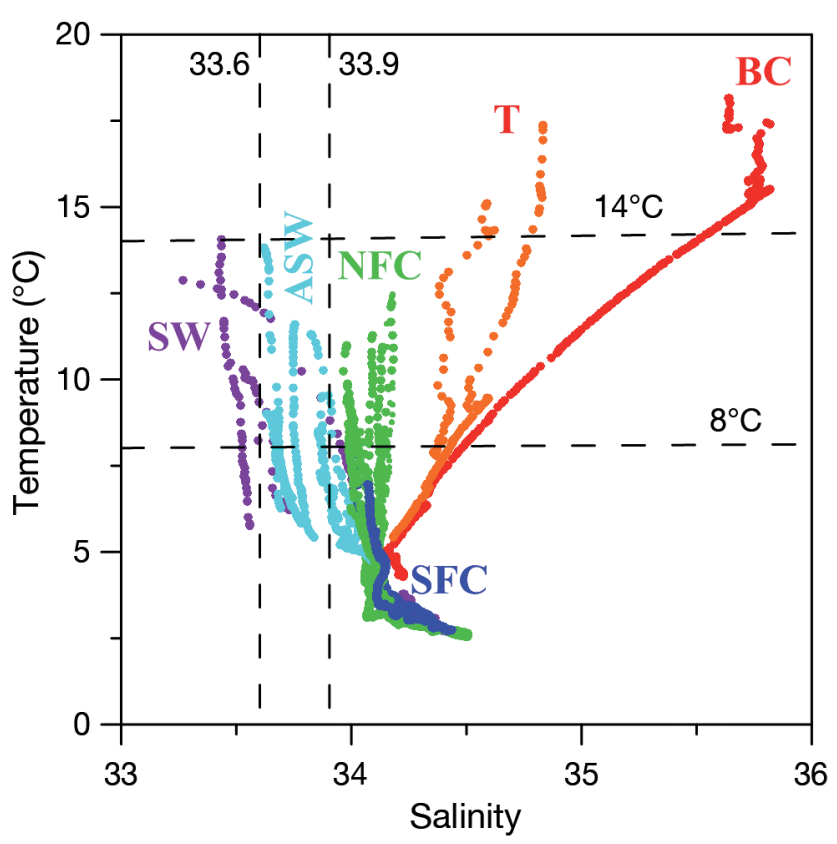

Fig. 4. Temperature versus salinity plot (full-depth CTD data). Stations are colour coded based on the analysis by Painter et al. (2010) of the major hydrographic provincesBC: Brazil Current; T: transitional; NFC: Northern Falklands Current; SFC: Southern Falklands Current; ASW: Antarctic shelf water; SW: shelf water. Vertical dashed lines indicate salinities of shelf waters, horizontal dashed lines separate warm subtropical and transitional waters, and Northern and Southern Falklands Current waters

(Fig. 3A). A temperature versus salinity plot for the full-depth CTD data (Fig. 4) showed the presence of several water masses along the Patagonian Shelf (see also Painter et al. 2010, Garcia et al. 2011), so that each sampling station could be classified within a water mass (Table 2): warm and high saline Brazil Current water (Stn 008); subtropical/temperate transitional warm and saline water (Stns 010, 014); Northern Falklands Current water with salinities of $\sim 34$ and $\mathrm{SST}>8^{\circ} \mathrm{C}$ (Stns $017,025,032,052,060,094$, 102, 108); Southern Falklands Current water with salinities of $\sim 34$ and $\mathrm{SST}<8^{\circ} \mathrm{C}$ (Stns 086, 122, 134); low salinity $(<34)$ shelf waters (Stns 005, 020, 068); and Antarctic shelf waters (Stns 040, 047, 072, 078, 090, $116,128,142$ ) with salinities between 33.6 and 33.9.

Surface macronutrient concentrations showed complex patterns over the Patagonian Shelf and in the surrounding waters (Fig. 3B). Surface nitrate was low

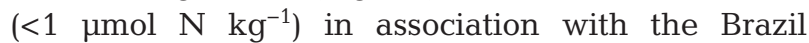
Current and transitional subtropical waters (Stns 005, $008,010)$ and at on-shelf stations north of $47^{\circ} \mathrm{S}$ (Stns 020,040 ) (Fig. 3B). Offshore stations north of $47^{\circ} \mathrm{S}$ (Stns 014, 017, 025, 032, 047, 052) had surface nitrate concentrations between 5 and $10 \mu \mathrm{mol} \mathrm{N} \mathrm{kg}{ }^{-1}$. South of $47^{\circ} \mathrm{S}$ all stations except for Stn 072 had surface ni- trate concentrations $>10 \mu \mathrm{mol} \mathrm{N} \mathrm{kg}{ }^{-1}$, independent of whether they were on or off-shelf (Fig. 3B). The highest surface nitrate concentration $\left(17 \mu \mathrm{mol} \mathrm{N} \mathrm{kg}^{-1}\right)$ was measured on Burwood Bank to the south of the Falkland Islands (Stn 134). Surface phosphate concentrations followed a very similar pattern to nitrate (Fig. 3B) with nitrate to phosphate (N:P) ratios $<16: 1$ for almost all stations, apart from Stn $014(\mathrm{~N}: \mathrm{P}=28)$. A notable trend in $\mathrm{N}: \mathrm{P}$ ratios was observed along the shelf, with northern stations $(005,008,010)$ and shelf stations $(020,040)$ having N:P ratios $<3$, while offshore stations had ratios between 10 and 14.3.

Along the cruise track, $\mathrm{pH}$ showed little variability, with most sampling stations having values from $~ 8.1$ to 8.2 (Fig. 3C). Two stations (Stns 072, 086) had $\mathrm{pH}$ values $>8.2$, and these were associated with high chlorophyll waters $\left(52.2\right.$ and $69.4 \mathrm{mg} \mathrm{m}^{-2}$, respectively; data not shown), although there was no overall relationship between $\mathrm{pH}$ and integrated water column chlorophyll concentrations (W. M. Balch unpubl. data). To the south of the shelf (Stns >090), variability in $\mathrm{pH}$ between sampling stations was much reduced (Fig. 3C). Calcite saturation states (i.e. $\Omega_{\text {cal- }}$ cite) generally decreased along the shelf, from values $>4$ in northern waters to values between 3.5 and 4 to the south of the Falkland Islands (Fig. 3C). Several stations had $\Omega_{\text {calcite }}$ values $>4.5$, and these were associated with warm subtropical and transitional waters (Stns 008, 010, 014) and shelf waters (Stns 020, 040) at the northern end of the transect.

Mixed-layer depths varied from 7 to $61 \mathrm{~m}$, with depths mostly $<20 \mathrm{~m}$ until Stn 086 and then they progressively deepened to $>50 \mathrm{~m}$ to the south of the Falklands Plateau (Fig. 3D). Euphotic zone depth closely followed the depth of the mixed layer (Fig. 3D) and was consistently from 5 to $20 \mathrm{~m}$ deeper than the mixed layer or at a similar depth until south of the Falklands Plateau, where the MLD was from 10 to $20 \mathrm{~m}$ deeper than the euphotic zone. Average mean mixed-layer irradiance $\left(\overline{\mathrm{E}}_{[\mathrm{ML}]}\right)$ was generally

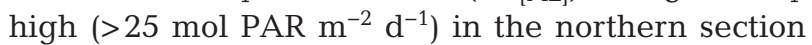

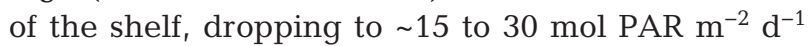
between Stns 047 and 108, and then to $<15$ mol PAR $\mathrm{m}^{-2} \mathrm{~d}^{-1}$ to the south of Stn 108 (Fig. 3E).

\section{Coccolithophore community dynamics}

The coccolithophore community of the Patagonian Shelf was formed of several distinct communities (Table 2, see also Fig. 3F): north of $47^{\circ} \mathrm{S}$ there were 2 main coccolithophore communities, one with stations dominated by species other than Emiliania huxleyi 
(i.e. Umbellosphaera tenuis, Syracosphaera delicata, $S$. marginaporata) and with cell densities $<0.2 \times$ $10^{3}$ cells ml ${ }^{-1}$ and another dominated by E. huxleyi, with cell densities ranging from $0.2 \times 10^{3}$ to $0.4 \times$ $10^{3}$ cells ml ${ }^{-1}$. The latter represented the northward extension of the coccolithophore bloom: south of $47^{\circ} \mathrm{S}, E$. huxleyi dominated the community with cell abundances ranging from $0.18 \times 10^{3}$ to $3.06 \times 10^{3}$ cells $\mathrm{ml}^{-1}$ (Fig. 3F). E. huxleyi coccolith densities showed a clearer picture of the extent of the Patagonian Shelf bloom, with stations in the northern tail of the bloom having coccolith densities $\sim 2 \times 10^{3} \mathrm{ml}^{-1}$ and higher, while in the central part of the bloom detached coccoliths were in excess of $10 \times 10^{3} \mathrm{ml}^{-1}$ (Table 2, Fig. 3F). We have used thresholds in the detached $E$. huxleyi coccolith counts to classify stations into nonbloom $\left(<1 \times 10^{3}\right.$ coccoliths $\left.\mathrm{ml}^{-1}\right)$, outer bloom $\left(1 \times 10^{3}\right.$ to $10 \times 10^{3}$ coccoliths $\left.\mathrm{ml}^{-1}\right)$ and central bloom $(>10 \times$ $10^{3}$ coccoliths $\mathrm{ml}^{-1}$ ) communities in Table 2 .

\section{Emiliania huxleyi morphotype distribution}

Generally, E. huxleyi coccoliths of Morphotype B/C represented the dominant morphotype along most of the Patagonian Shelf (10 to $100 \%$ of the total at each station), although the A morphotype (0 to $90 \%$ ) was also present at some stations (Fig. 5A). Morphotype A coccoliths appeared dominant ( $>50$ to $70 \%$ ) at several stations, including those associated with the Brazil Current and the subtropical transitional zone (Stns 008, 010, 014), as well as those associated with shelf waters both to the north of the Falklands (Stns 005, 020, 040, 068, 072) and to the south (Stns 128, 142) (Fig. 5B). Several important observations should be noted: (1) Morphotype B/C dominated the community at several stations along the shelf (Stns 017, 025, 032, 060, 078, 090, 122), (2) at several stations the community was almost evenly split between the 2 morphotypes (Stns 040, 128, 142), (3) Morphotype B/C was present at all stations, while Morphotype A was absent from several, and (4) the offshore Patagonian Shelf bloom was characterised by Morphotype B/C.

\section{Emiliania huxleyi morphotypes and envi- ronmental variables}

In order to explore the relationship between the environmental variables and the abundance of the E. huxleyi morphotypes, a PCA was carried out using normalised environmental variables (Fig. 3; SST, salinity, nitrate and phosphate concentrations, $\mathrm{pH}, \Omega_{\text {calciter }}$ and $\left.\overline{\mathrm{E}} \mathrm{d}_{[\mathrm{ML}]}\right]$. The first PC (PC-1) explained $60.5 \%$ of the variance between stations in terms of the selected environmental variables, with PC-2 explaining another $17.7 \%$ of the variance. PC-3, PC-4 and PC-5 explained another $13.6,6.4$ and $1.4 \%$ of the variance, respectively, between stations. Hence, when combined PC-1 and PC-2 explained $78.2 \%$ of the variance, with the combination of all 5 PCs explaining $99.5 \%$. A plot of PC1 and PC-2 scores (Fig. 6A) shows how the sampling stations differed with respect to one another. Stations at the northern end of the transect (Stns 008, 010, 014) were clearly separate from the main trend for the other sampling stations.

The eigenvalues from PCA are given in Table 3, indicating the relative weight of the environmental variables in influencing each of the PCs. Furthermore, Pearson moment correlations with PC-1 (in brackets in Table 3) showed statistically significant $(\mathrm{p}<0.005)$ correlations for both nitrate and phosphate (both positive) and for SST, $\overline{\mathrm{E}} \mathrm{d}_{[\mathrm{ML}]}, \mathrm{pH}$ and $\Omega_{\text {calcite }}$ (all negative). Essentially, PC-1 described the north-south gradient of sampling stations from warm, nutrient-poor water with relatively high $\Omega_{\text {calcite }}$ to the north of the Patagonian Shelf to cold, nutrient-

Table 3. Results of principal component (PC) analysis, including eigenvectors and Pearson correlation coefficients for the relationships between PC scores, environmental variables, morphotype abundances and median coccolith calcite. Absolute morphotype abundances have been log-transformed. ${ }^{*} \mathrm{p}<0.05,{ }^{* *} \mathrm{p}<0.01 ;{ }^{* * *} \mathbf{p}<\mathbf{0 . 0 0 5}$

\begin{tabular}{|c|c|c|}
\hline \multirow[t]{2}{*}{ Variables } & \multicolumn{2}{|c|}{ Variables vs. principal components } \\
\hline & $\mathrm{PC}-1$ & PC-2 \\
\hline \multicolumn{3}{|l|}{ Environmental } \\
\hline Sea-surface temperature & $-0.45\left(-\mathbf{0 . 9 3} 3^{* * *}\right)$ & $-0.26(-0.29)$ \\
\hline Salinity & $-0.23(-0.47)$ & $-0.71\left(-\mathbf{0 . 7 9} \mathbf{9}^{* * *}\right)$ \\
\hline Nitrate & $0.44(\mathbf{0 . 9 0 * * *})$ & $-0.15(-0.17)$ \\
\hline Phosphate & $0.47\left(\mathbf{0 . 9 7 ^ { * * * }}\right)$ & $0.03(0.04)$ \\
\hline Average mixed-layer irradiance & $-0.16(-0.32)$ & $0.05(0.05)$ \\
\hline $\mathrm{pH}$ & $-0.29(-\mathbf{0 . 5 9 * * *})$ & $0.63\left(\mathbf{0 . 7 0} 0^{* * *}\right)$ \\
\hline Calcite saturation & $-0.48(-\mathbf{0 . 9 8 * * *})$ & $0.08(0.09)$ \\
\hline (n) & (23) & (23) \\
\hline \multicolumn{3}{|l|}{ Relative abundance } \\
\hline Morphotype A & $-0.71^{* * *}$ & -0.09 \\
\hline Morphotype B/C & $0.56^{* * *}$ & 0.05 \\
\hline \multicolumn{3}{|l|}{ Absolute abundance (log) } \\
\hline Morphotype A & 0.40 & $0.53^{*}$ \\
\hline Morphotype B/C & $0.76^{* * *}$ & 0.27 \\
\hline \multicolumn{3}{|l|}{ Coccolith calcite } \\
\hline Morphotype A & $0.55^{*}$ & 0.16 \\
\hline Morphotype B/C & -0.01 & $0.50^{* *}$ \\
\hline
\end{tabular}


(A)

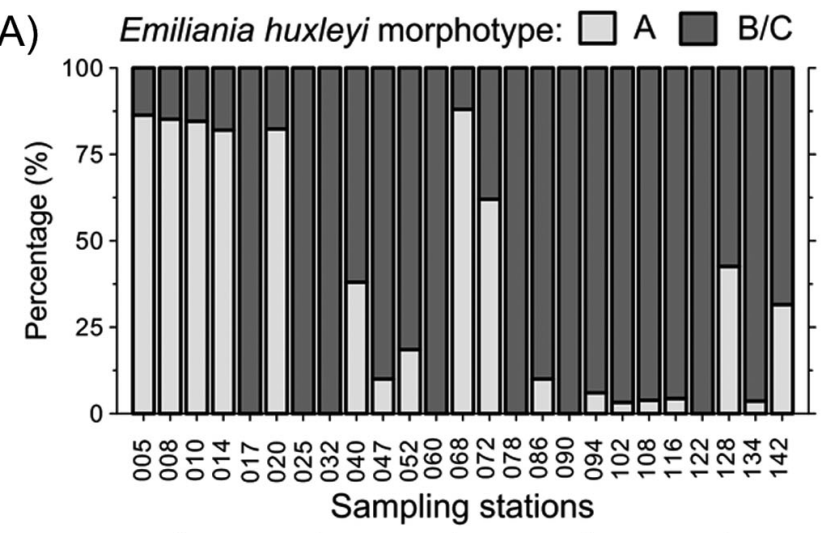

(B)

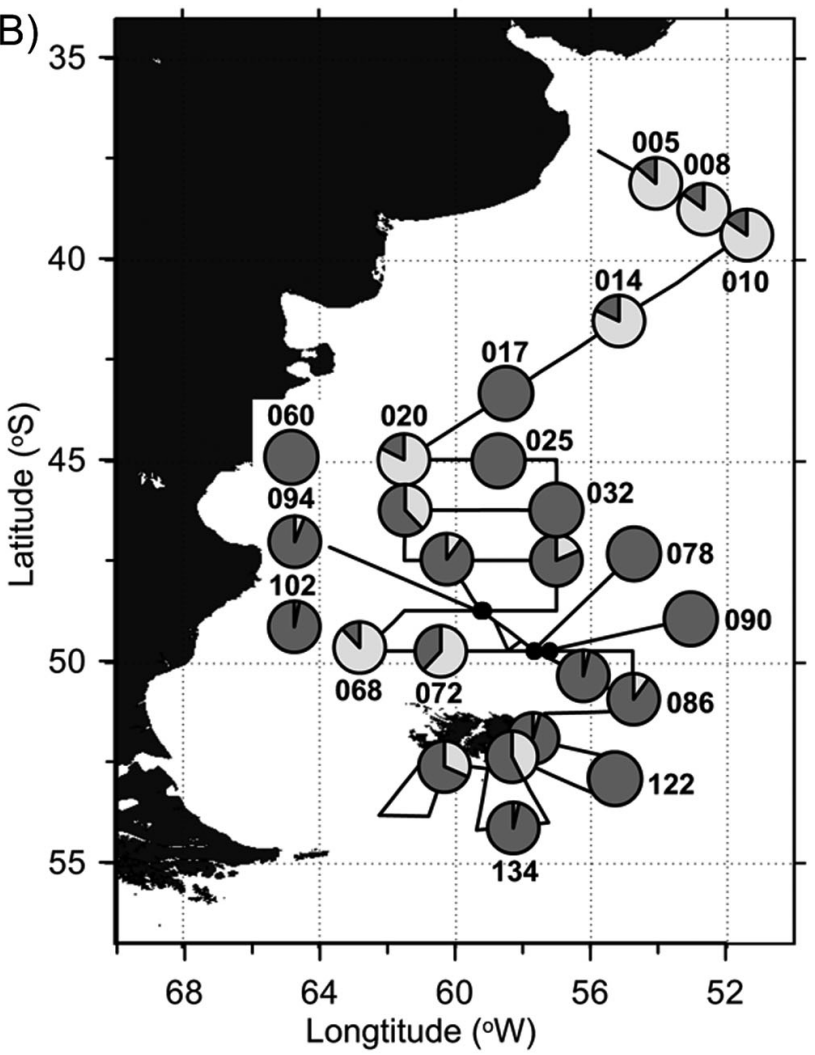

Fig. 5. Emiliania huxleyi. Percentage morphotype distribution along the cruise transect in terms of (A) sampling stations and (B) location along the Patagonian Shelf. Morphotypes are shaded identically in Panels A and B. Piecharts in (B) for sampling stations in similar geographical positions (i.e. Stns 060, 094 and 102; Stns 078 and 090) have been moved for clarity

rich waters with lower $\Omega_{\text {calcite }}$ to the south of the Falklands Plateau (Fig. 3). Pearson moment correlations with PC-2 (Table 3 ) showed statistically significant $(p<0.005)$ correlations with salinity (negative) and $\mathrm{pH}$ (positive), with $\mathrm{PC}-2$ partly explaining the inshore-offshore gradient in salinity and the slight gradient in $\mathrm{pH}$ down the cruise transect (Fig. 3).
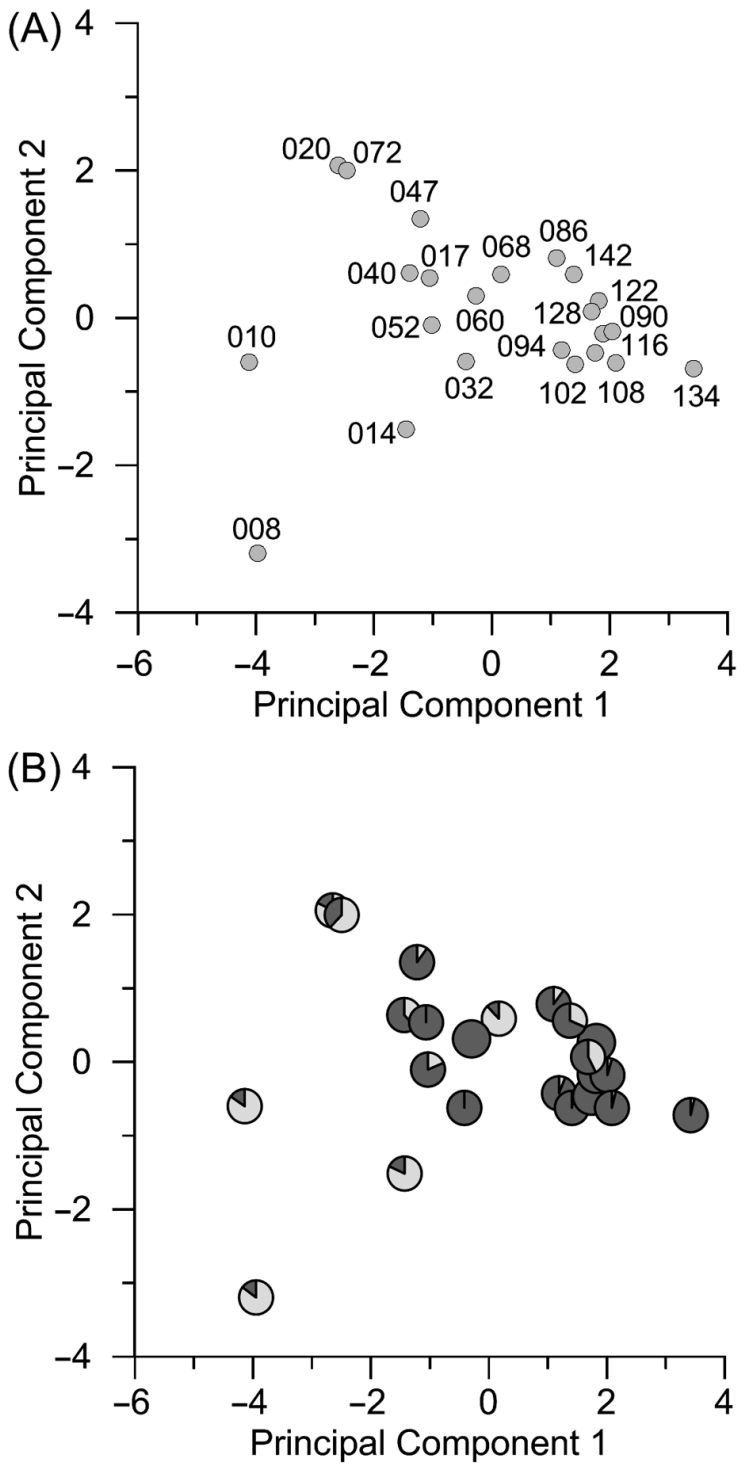

Fig. 6. Scatter plots of the first 2 principal components from PCA of the environmental variables. In Panel A, sampling stations are identified, while in Panel $B$, the percentage abundance of each morphotype is indicated (same shading as in Fig. 5)

Fig. 6B shows how the relative abundance of the 2 morphotypes changes along the first $2 \mathrm{PCs}$, with these relationships being further explored through Pearson moment correlations (Table 3). Pearson moment correlations between PC-1 and the relative abundance of each morphotype showed a significant $(\mathrm{p}<0.005)$ anti-correlation with Morphotype A and a significant $(\mathrm{p}<0.005)$ correlation with Morphotype B/C (Table 3). No significant correlations were evident between PC-2 and the different morphotypes. These relationships highlight how the relative abundance of Morphotype B/C increased towards the 
southern end of the transect, with decreasing SST and $\Omega_{\text {calcite }}$ and increasing nitrate and phosphate concentrations. Conversely, the relative abundance of Morphotype A increased towards the northern end of the transect with increasing SST and $\Omega_{\text {calcite }}$ and decreasing nitrate and phosphate concentrations. Examination of the relationship between the nitrate: phosphate ratio and morphotype relative abundance showed a significant anti-correlation with the A morphotype $(\mathrm{r}=-0.72, \mathrm{p}<0.005, \mathrm{n}=16)$ and a significant correlation with Morphotype B/C $(r=0.57, p<0.005$, $\mathrm{n}=16)$.
Clearly, the relative abundance of the 2 morphotypes will have an anti-correlation; hence, it is appropriate to also examine the trends in absolute abundances in relation to the environmental parameters, PC-1 and PC-2. Pearson moment correlations between PC-1 and the absolute abundance of Morphotype $B / C$ showed a significant $(p<0.005)$ correlation (Table 3), emphasising the increased abundance of $\mathrm{B} / \mathrm{C}$ in the cold, nutrient-rich waters with lower $\Omega_{\text {cal- }}$ cite to the south of the Patagonian Shelf. A correlation was also present between the absolute abundance of Morphotype A and PC-2, although at a lower level of

Morphotype A $\quad$ Morphotype B/C
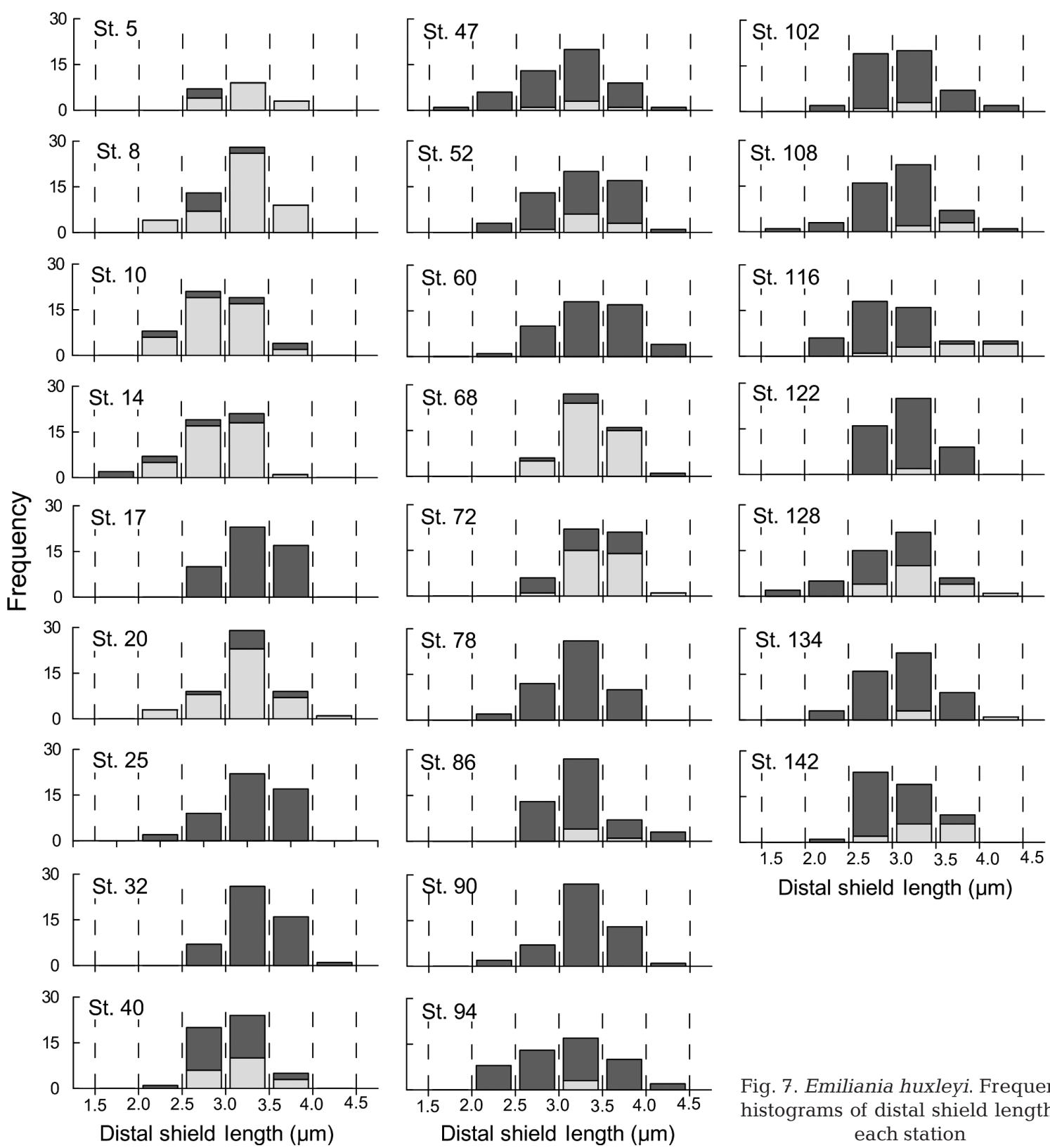

Fig. 7. Emiliania huxleyi. Frequency histograms of distal shield length at each station 
significance $(p<0.05)$. The absolute abundance of Morphotype B/C and the nitrate:phosphate ratio also showed a statistically significant positive relationship $(\mathrm{r}=0.57, \mathrm{p}<0.005, \mathrm{n}=23)$.

\section{Variability in Emiliania huxleyi coccolith dimensions and calcite content}

Frequency histograms of the DSL for the different stations and different morphotypes (Fig. 7) were generally unimodal (see also Triantaphyllou et al. 2010). The lack of obvious bimodality, despite the varying dominance of 2 distinct morphotypes, reflects the fact that $\mathrm{A}$ and $\mathrm{B} / \mathrm{C}$ produce coccoliths of similar size ranges (Fig. 7). There was also no clear relationship between DSL frequency for either morphotype and the sampling stations in terms of lati- tude, inshore/offshore, or hydrographic province. For stations with Morphotype A present, $83 \%$ had a median DSL of 3.01 to $3.5 \mu \mathrm{m}$ and $17 \%$ had a median DSL of 2.51 to $3.0 \mu \mathrm{m}$. For stations with Morphotype B/C, $75 \%$ of stations had a median DSL of 3.01 to $3.5 \mu \mathrm{m}$ and $25 \%$ had a median DSL of 2.51 to $3.0 \mu \mathrm{m}$. Overall, the majority of the detached coccoliths in the waters of the Patagonian Shelf had a DSL between 3.01 and $3.5 \mu \mathrm{m}$.

The calcite content of individual coccoliths is a function of volume and so of length (DSL) cubed (Young \& Ziveri 2000; Table 1). Hence, knowing the species' or population's DSL frequency and the relative morphotype abundance (i.e. $k_{\mathrm{s}}$ values for the population) it is possible to convert DSL into coccolith calcite content (see Eq. 1) and plot the values for each morphotype at each of the sampling stations along the Patagonian Shelf.
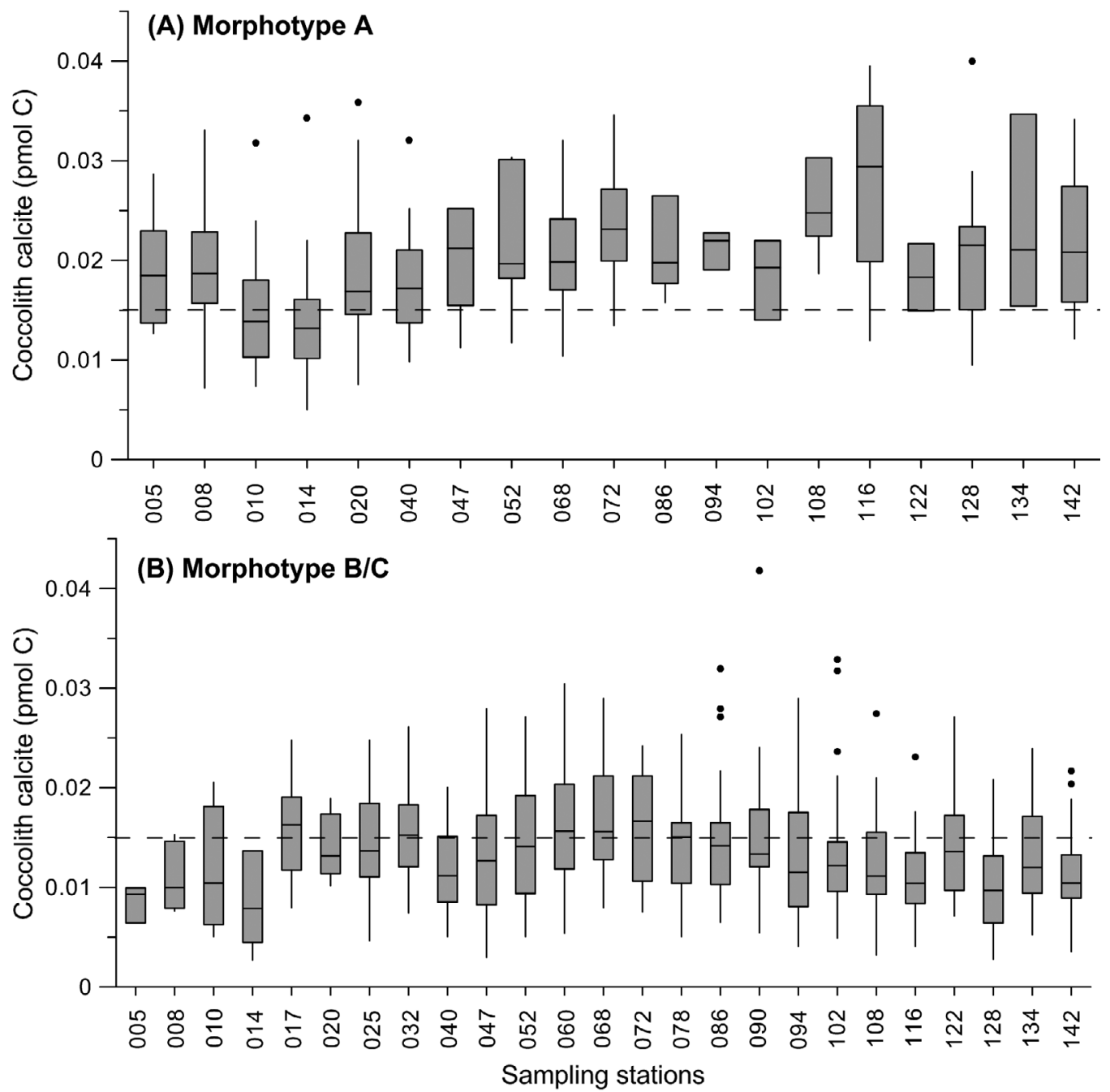

Fig. 8. Emiliania huxleyi. Box-whisker plots of estimated coccolith calcite for (A) Morphotype A and (B) Morphotype B/C. Dashed lines indicate the median values for all coccoliths of each morphotype. Box-whisker plots include the minimum value, lower quartile, median, upper quartile and maximum value, as well as possible outliers (black dots) 
Fig. 8 presents the coccolith calcite contents for the detached coccoliths of Morphotypes A (Fig. 8A) and B/C (Fig. 8B) in the form of box-whisker plots (i.e. including the minimum value, lower quartile, median, upper quartile and maximum value, as well as possible outliers). Clearly there is variability in median coccolith calcite quotas between stations and between morphotypes, with coccoliths of the A morphotype having higher values (Fig. 8A) than those for B/C (Fig. 8B). The average $( \pm \mathrm{SD})$ calcite quota for all Morphotype A coccoliths from the Patagonian Shelf was $0.019( \pm 0.007)$ pmol $\mathrm{C}$ coccolith $^{-1}$ and the average $( \pm \mathrm{SD})$ for all Morphotype B/C coccoliths was $0.014( \pm 0.005) \mathrm{pmol} \mathrm{C} \mathrm{coccolith}^{-1}$. The average $( \pm \mathrm{SD})$ for the combination of coccoliths from both morphotypes was $0.015( \pm 0.006)$ pmol C coccolith ${ }^{-1}$. The difference in calcite quotas between the morphotypes is due to the higher $k_{\mathrm{s}}$ value used for $\mathrm{A}$ than for $\mathrm{B} / \mathrm{C}$ (see Table 1), reflecting the fact that it is characteristically more heavily calcified, rather than differences in DSL (Fig. 7).

Comparison of median coccolith calcite values for both Morphotypes A and B/C, with the PCs describing the variability in the environmental conditions along the shelf, showed correlations between Type A coccolith calcite and PC-1 and between B/C coccolith calcite and PC-2 (Table 3). Both correlations were at weaker levels of significant ( $p<0.05$ for Morphotype A and $\mathrm{p}<0.01$ for Morphotype B/C) than for those of the relationships observed between morphotype relative abundance and the PCs $(\mathrm{p}<0.005)$.

\section{DISCUSSION}

\section{Morphotype distribution along the Patagonian Shelf}

The 2 morphotypes of Emiliania huxleyi present along the Patagonian Shelf (A and B/C) had distinctly different spatial distributions (Fig. 5B). Morphotype A was relatively more abundant in warm waters with low nitrate and phosphate concentrations and higher saturation states, as found at the northern end of the shelf and in some shelf waters. Morphotype B/C was relatively more abundant in cold waters with high nitrate and phosphate concentrations and lower saturation states, as found towards the southern end of the shelf. These differences are clear from the PCA and Pearson product-moment correlations between $\mathrm{PC}-1$, the environmental variables and the relative abundance of each morphotype (Table 3). The absolute abundance of Morphotype B/C coccoliths was also significantly related to the strong gradient in environmental variables along the shelf, indicating that the offshore coccolithophore bloom in 2008 occurred in cold, nutrient-rich waters with lower calcite saturation states than at the northern end of the transect. Correlations do not necessarily mean causation; hence, it is unclear whether the formation and maintenance of the 2008 bloom, dominated by Morphotype B/C, was linked to these conditions, or rather if these conditions only characterised the hydrographic province in which the bloom occurred.

Painter et al. (2010) recently concluded for the COPAS'08 bloom that the combination of factors favourable for bloom formation (e.g. high N:Si, shallow MLD; see Tyrrell \& Merico 2004; see also Garcia et al. 2011) were found to be relatively more stable in the Antarctic shelf water mass than in other water masses along the Patagonian Shelf. These authors concluded this from examination of satellite data and in situ hydrographic and current data. Our study supports the conclusions of Painter et al. (2010) in that (1) the morphotype relative and absolute abundance was strongly linked to the hydrographic drivers along the shelf, and (2) the absolute abundance of the morphotype dominating the bloom (B/C) was strongly linked to factors previously associated with bloom formation (nitrate concentration and N:P ratio; Tyrrell \& Merico 2004). Importantly, the Patagonian Shelf bloom differs from many blooms in that the abundance of Morphotype B/C was positively correlated with $\mathrm{N}: \mathrm{P}$; hence, the bloom appears to favour elevated $N: P$ ratios rather than low $N: P$ (see also Lessard et al. 2005). However, both nitrate and phosphate were in concentrations ( $>8 \mu \mathrm{mol} \mathrm{N} \mathrm{kg}{ }^{-1}$ and $0.5 \mu \mathrm{mol}$ $\mathrm{P} \mathrm{kg}^{-1}$, respectively) not likely to be limiting, rather than the low concentrations $\left(<3 \mu \mathrm{mol} \mathrm{N} \mathrm{kg}{ }^{-1}\right)$ found in bloom waters in the North Atlantic Ocean (e.g. Fernandez et al. 1993).

In summary, the strong hydrographic differences along the Patagonian Shelf resulted in strong differences in the composition of the Emiliania huxleyi community in terms of morphotypes. Although our study of the Patagonian Shelf found Morphotype A to be restricted to low-salinity shelf waters and warm $\left(>10^{\circ} \mathrm{C}\right)$ subtropical transitional waters to the north of the shelf (Fig. 5B), other studies have found Morphotype A both in coastal environments, such as Norwegian fjords (e.g. Batvik et al. 1997), and in more offshore environments, such as the equatorial Pacific (Hagino \& Okada 2006) and central Iceland Basin, during both bloom (Holligan et al. 1993) and nonbloom (Poulton et al. 2010) conditions. Morphotype $\mathrm{B} / \mathrm{C}$, in contrast, appears to be more common in 
cold $\left(<10^{\circ} \mathrm{C}\right)$, nutrient-rich southern waters (Findlay \& Giraudeau 2000, Cubillos et al. 2007, Holligan et al. 2010, present study). Dominance of the 2008 Patagonian Shelf coccolithophore bloom by the B/C morphotype supports the conclusion that this morphotype dominates subpolar communities in the Southern Ocean (Findlay \& Giraudeau 2000, Cubillos et al. 2007) and implies that blooms observed in reflectance data around the Scotia Sea (Holligan et al. 2010) may also be of this morphotype.

\section{Coccolith calcite quotas}

Previous field-based estimates of coccolith calcite have used the slope of the regression between particulate calcium (particulate inorganic calcite, PIC) measurements and the sum of detached and cell-attached coccoliths to derive a per coccolith calcite quota (e.g. Fernandez et al. 1993, Poulton et al. 2010). These have led to estimates of coccolith calcite of $\sim 0.035 \mathrm{pmol} \mathrm{C}$, with differences in studies being explained by the influence of aggregates (e.g. faecal pellets). Birefringence-based estimates of Emiliania huxleyi coccolith calcite give values of $\sim 0.050$ to $0.070 \mathrm{pmol} \mathrm{C}$ (Beaufort 2005), considerably higher than other estimates. In fact, a regression of particulate calcite measurements and total coccoliths derived from SEM counts for the COPAS'08 surface measurements gives a coccolith calcite value of $0.033 \mathrm{pmol} \mathrm{C}\left(\mathrm{r}^{2}=0.89, \mathrm{n}=24, \mathrm{p}<\right.$ 0.001). This is significantly higher than our estimates based on DSL (Fig. 8). Differences in coccolith calcite between the present study and those in the North Atlantic (Fernandez et al. 1993, Poulton et al. 2010) may be related to the dominant morphotype of $E$. huxleyi present (A in North Atlantic) or to the method of estimating the coccolith calcite. However, Holligan et al. (2010), working in the Scotia Sea to the south of the Patagonian Shelf, found a relatively low mean value of coccolith calcite $(0.022 \mathrm{pmol} \mathrm{C})$, similar to our estimates from DSL $(0.015 \mathrm{pmol} \mathrm{C})$, based on the slope of the regression line between total coccoliths and PIC measurements. Another significant source of error may be in the constant $k_{\mathrm{s}}$ value assumed for each morphotype (Table 1), with much more work required on the magnitude of variability in $k_{\mathrm{s}}$ in both culture and field populations. Furthermore, intercomparison of the different methods for estimating coccolith calcite content (regression, birefringence, morphometrics) is needed.

Differences in coccolith calcite between morphotypes of Emiliania huxleyi potentially drive the differences in calcite production among the different com- munities (Cubillos et al. 2007). However, this largely depends on whether or not the different morphotypes are producing the same number of coccoliths per unit time or fixing the same amount of carbon via calcification per unit time. Laboratory studies addressing this issue are currently unavailable, although clearly of relevance to the interpretation of field data. The results from the Patagonian Shelf also highlight the fact that natural field populations of $E$. huxleyi are producing coccoliths with a wide range of DSL and hence coccolith calcite. For the Patagonian Shelf, this is true for each individual morphotype and the combination of the 2 (Figs. $7 \& 8$ ). In fact, despite strong patterns in the relative abundance of E. huxleyi morphotypes along the shelf (Fig. 5), there is considerable overlap in the range of coccolith sizes and calcite quotas for these populations (Figs. $7 \& 8$ ). Although the morphotypes have distinctly differentsized coccoliths, with different calcite quotas, the size range over which these morphotypes are producing coccoliths is similar and acts to mask their distribution patterns.

\section{Genotypic variability}

Although Emiliania huxleyi is often regarded as a globally ubiquitous species, the truth appears to be rather that it has a variety of morphotypes and genotypes able to exist successfully in a wide variety of marine environments (Young \& Westbroek 1991, Paasche 2001). These different morphotypes appear to be biochemically and genetically distinct (Van Bleijkswijk et al. 1994, Young \& Westbroek 1991, Medlin et al. 1996, Schroeder et al. 2005, IglesiasRodriguez et al. 2006, Cook et al. 2011), with clonal cultures retaining their characteristic morphotype for multiple generations (Young \& Westbroek 1991, Cubillos et al. 2007, Cook et al. 2011). However, there is also a high degree of intra-population genetic diversity, with geographically distinct populations appearing to be non-clonal (Medlin et al. 1996, IglesiasRodriguez et al. 2002b, 2006, Cook et al. 2011). Hence, mono-specific blooms of E. huxleyi are actually composed of an array of coexisting genotypes or clones (i.e. strains of E. huxleyi with distinct genotypes) (Medlin et al. 1996, Paasche 2001, Iglesias-Rodriguez et al. 2002b, 2006). Few laboratory studies have addressed whether the different morphotypes are physiologically different, although Van Bleijswijk et al. (1994) did find physiological differences between clonal strains of Morphotypes A and B, including differences in growth rates, cell size, chlorophyll fluo- 
rescence, rates of calcification and photosynthesis, and response to irradiance. A recent study by Cook et al. (2011) found significant differences in the photosynthetic pigments present in strains of Morphotypes A and B/C isolated from the Southern Ocean.

Clearly, the field data collected from the Patagonian Shelf show the presence of 2 morphotypes, each with a slightly different distribution (Fig. 5) and unique responses to environmental gradients (Table 3). These differences imply that the morphotypes can be viewed as distinctive ecotypes, each suited to a different environment (see also Cook et al. 2011). How genetically similar the station populations are to one another, either between morphotypes or within morphotypes, is unclear but warrants future attention. Dominance of the different blooms (shelf vs. offshore) by the different morphotypes, within a relatively small area and occurring at the same time, indicates that genetically, and potentially physiologically, distinct blooms can occur within relatively small spatial, temporal and ecological scales. Hence, large-scale Emiliania huxleyi blooms occurring along strong hydrographic gradients may actually be composed of morphologically, genetically and physiologically distinct populations, which have distinct environmental drivers. More in situ sampling of these large-scale features and further comparative studies between morphotypes are both required.

\section{Future directions}

In light of the potential differences in morphotype ecology and physiology, it seems apparent that the factors driving coccolithophore blooms and openocean dynamics should be widened from those currently associated with blooms in the North Atlantic Ocean. For example, salinity and temperature appear to be important factors regulating morphotype abundance along the Patagonian Shelf. Examining morphotype abundance (absolute and relative) at the basin scale, and in the context of hydrographic parameters, would help to clarify the factors, and their relative influence, which regulate coccolithophore calcite production. Coupling genotypic and biometric laboratory and field studies should also provide considerable insight into the population dynamics of oceanic coccolithophore populations. Importantly, 2 points with global significance come out of the observations of the Patagonian Shelf Emiliania huxleyi population: (1) different morphotypes of $E$. huxleyi may dominate blooms in different geographical areas and (2) morphotype biogeography may not be rigid.
In the context of the current research focus on the effects of ocean acidification (e.g. Doney et al. 2009), it should be clear that any field study must consider changes in cellular calcification both in absolute and cell-normalised terms, and also in the context of changes in either the coccolith dimensions and/or relative morphotype abundances. Inter-strain variability in the response of coccolithophores to manipulations of the carbonate chemistry (e.g. Langer et al. 2009) are now being recognised as important for understanding the effects of ocean acidification on coccolithophores. Our study highlights that there is also the potential for inter-strain and inter-type variability in the response of Emiliania huxleyi to physiological drivers (e.g. light, nutrient concentrations). Overcoming such intra-species variability, so that results from laboratory and field studies can be extrapolated to ecological and global modelling studies, will require that 2 key questions are addressed: (1) Are there ecophysiological models (ecotypes) within or between strains? (2) How definitive are these ecotypes in terms of predicting their response to environmental conditions?

Acknowledgements. We thank Stuart Painter (NOCS) for assistance with satellite imagery and interpretation of the physical environment, Stephanie Henson (NOCS) for assistance with satellite PAR data, Bruce Bowler (BLOS) for assistance with field sampling and filtering, Marlene Jeffries, Keven Neely, Rebecca Garley (BIOS) and Nicole Beniot (WHOI) for seawater carbonate chemistry sampling, Dan Shultz (SCRIPPS) for macronutrient data, and Richard Pearce (NOCS) for assistance with SEM preparation. We are also very grateful to 4 anonymous reviewers for their suggestions and comments on an early version of the paper. MODIS Aqua data were obtained from the NASA Ocean Colour distributed archive (http://oceancolor.gsfc.nasa.gov/). Participation of A.J.P. was supported by Oceans 2025 funding, with further financial support from the Natural Environmental Research Council via a postdoctoral fellowship (NE/F015054/1). W.M.B. was supported by NSF (OCE0728582 and OCE-0961660) and NASA (NNX08AJ88A and NNX08AAB10G).

\section{LITERATURE CITED}

Balch WM, Kilpatrick K, Holligan PM, Cucci T (1993) Coccolith production and detachment by Emiliania huxleyi (Prymnesiophyceae). J Phycol 29:566-575

Balch WM, Poulton AJ, Drapeau DT, Bowler BC, Windecker LA, Booth ES (2011) Zonal and meridional patterns of phytoplankton biomass and carbon fixation in the Equatorial Pacific Ocean, between $110^{\circ} \mathrm{W}$ and $140^{\circ} \mathrm{W}$. DeepSea Res II 58:400-416

Bates NR, Michaels AF, Knap AH (1996) Seasonal and interannual variability of oceanic carbon dioxide species at the US JGOFS Bermuda Atlantic time-series study (BATS) site. Deep-Sea Res II 43:347-383 
Batvik H, Heimdal BR, Fagerbakke KM, Green JC (1997) Effects of unbalanced nutrient regime on coccolith morphology and size in Emiliania huxleyi (Prymnesiophyceae). Eur J Phycol 32:155-165

- Baumann KH (2004) Importance of size measurements on coccolith carbonate flux estimates. Micropaleontology 50:35-43

> Beaufort L (2005) Weight estimates of coccoliths using the optical properties (birefringence) of calcite. Micropaleontology 51:289-298

Beaufort L, Couapel M, Buchet N, Claustre N, Goyet C (2008) Calcite production by coccolithophores in the south east Pacific Ocean. Biogeosciences 5:1101-1117

> Bollmann J, Herrle JO, Cortés MY, Fielding SR (2009) The effect of sea water salinity on the morphology of Emiliania huxleyi in plankton and sediment samples. Earth Planet Sci Lett 284:320-328

> Cook SS, Whittock L, Wright SW, Hallegraeff GM (2011) Photosynthetic pigment and genetic differences between two Southern Ocean morphotypes of Emiliania huxleyi (Haptophyta). J Phycol 47:615-626

Cubillos J, Wright S, Nash G, de Salas M and others (2007) Calcification morphotypes of the coccolithophorid Emiliania huxleyi in the Southern Ocean: changes in 2001 to 2006 compared to historical data. Mar Ecol Prog Ser 348: 47-54

> Dickson AG, Millero FJ (1987) A comparison of the equilibrium constants for the dissociation of carbonic acid in seawater media. Deep-Sea Res Part A 34:1733-1743

Dickson AG, Sabine CL, Christian JR (2007) Guide to best practices for ocean $\mathrm{CO}_{2}$ measurements. PICES Special Publication Vol 3, IOCCP report no. 8

$>$ Doney SC, Balch WM, Fabry VJ, Feely RA (2009) Ocean acidification: a critical emerging problem for the ocean sciences. Oceanography 22:16-26

- Fernandez E, Boyd P, Holligan PM, Harbour DS (1993) Production of organic and inorganic carbon within a largescale coccolithophore bloom in the northeast Atlantic Ocean. Mar Ecol Prog Ser 97:271-285

Findlay CS, Giraudeau J (2000) Extant calcareous nanoplankton in the Australian Sector of the Southern Ocean (austral summers 1994 and 1995). Mar Micropaleontol 40:417-439

Garcia CAE, Garcia VMT, Dogliotti AI, Ferreira A and others (2011) Environmental conditions and bio-optical signature of a coccolithophorid bloom in the Patagonian Shelf. J Geophys Res 116:C03025, doi:10.1029/2010JC 006595

Gordon HR, Du T (2001) Light scattering by nonspherical particles: application to coccoliths detached from Emiliania huxleyi. Limnol Oceanogr 46:1438-1454

Gordon HR, Smyth TJ, Balch WM, Boynton GC, Tarran GA (2009) Light scattering by coccoliths detached from Emiliania huxleyi. Appl Opt 48:6059-6073

Grasshoff K, Ehrhardt M, Kremling K (1983) Methods of seawater analysis. Verlag Chemie, Weinheim

Hagino K, Okada H (2006) Intra- and infra-specific morphological variation in selected coccolithophore species in the equatorial and subequatorial Pacific Ocean. Mar Micropaleontol 58:184-206

> Hagino K, Okada H, Matsuoka H (2005) Coccolithophore assemblages and morphotypes of Emiliania huxleyi in the boundary zone between the cold Oyashio and warm Kuroshio currents off the coast of Japan. Mar Micropaleontol 55:19-47
Holligan P, Fernandez E, Aiken J, Balch WM and others (1993) A biogeochemical study of the coccolithophore, Emiliania huxleyi, in the North Atlantic. Global Biogeochem Cycles 7:879-900

Holligan PM, Charalampopoulou A, Hutson R (2010) Seasonal distributions of the coccolithophore, Emiliania huxleyi, and of particulate inorganic carbon in surface waters of the Scotia Sea. J Mar Syst 82:195-205

Iglesias-Rodriguez MD, Brown C, Doney S, Kleypas J and others (2002a) Representing key phytoplankton functional groups in ocean carbon cycle models: coccolithophorids. Global Biogeochem Cycles 16:47-1-47-20

Iglesias-Rodriguez MD, Saez AG, Groben R, Edwards KJ, Batley J, Medlin L, Hayes P (2002b) Polymorphic microsatellites in global populations of the marine coccolithophorid Emiliania huxleyi. Mol Ecol Notes 2:495-497

> Iglesias-Rodriguez MD, Schofield OM, Batley J, Medlin LK, Hayes PK (2006) Intraspecific genetic diversity in the marine coccolithophore Emiliania huxleyi (Prymnesiophyceae): the use of microsatellite analysis in marine phytoplankton population studies. J Phycol 42:526-536

Kirk JTO (1994) Light and photosynthesis in aquatic ecosystems, 2nd edn. Cambridge University Press, Cambridge

Langer G, Nehrke G, Probert I, Ly J, Ziveri P (2009) Strainspecific responses of Emiliania huxleyi to changing seawater carbonate chemistry. Biogeosciences 6:2637-2646

Lessard EJ, Merico A, Tyrrell T (2005) Nitrate:phosphate ratios and Emiliania huxleyi blooms. Limnol Oceanogr 50:1020-1024

> Medlin LK, Barker GLA, Campbell L, Green JC and others (1996) Genetic characterisation of Emiliania huxleyi (Haptophyta). J Mar Syst 9:13-32

> Mehrbach C, Culberson CH, Hawley JE, Pytkowicz RM (1973) Measurement of the apparent dissociation constants of carbonic acid in seawater at atmospheric pressure. Limnol Oceanogr 18:897-907

Müller M, Antia A, Laroche J (2008) Influence of cell cycle phase on calcification in the coccolithophore Emiliania huxleyi. Limnol Oceanogr 53:506-512

Paasche E (1998) Roles of nitrogen and phosphorus in coccolith formation in Emiliania huxleyi (Prumnesiophyceae). Eur J Phycol 33:33-42

> Paasche E (2001) A review of the coccolithophorid Emiliania huxleyi (Prymnesiophyceae), with particular reference to growth, coccolith formation, and calcification-photosynthesis interactions. Phycologia 40:503-529

> Paasche E, Brubak S, Skattebøl S, Young JR, Green JC (1996) Growth and calcification in the coccolithophorid Emiliania huxleyi (Haptophyceae) at low salinities. Phycologia 35:394-403

> Painter SC, Poulton AJ, Allen JT, Pidcock R, Balch WM (2010) The COPAS'08 expedition to the Patagonian Shelf: physical and environmental conditions during the 2008 coccolithophore bloom. Cont Shelf Res 30: 1907-1923

Pierrot DE, Lewis E, Wallace DWR (2006) MS Excel program developed for $\mathrm{CO}_{2}$ system calculations. ORNL/CDIAC105a, Carbon Dioxide Information Analysis Centre, Oak Ridge National Laboratory, US Department of Energy, Oak Ridge, TN

> Poulton AJ, Charalampopoulou A, Young J, Tarran G, Lucas MI, Quartly GD (2010) Coccolithophore dynamics in non-bloom conditions during late summer in the central Iceland Basin (July-August, 2007). Limnol Oceanogr 55: 1601-1613 
Satoh M, Iwamoto K, Suzuki I, Shiraiwa Y (2009) Cold stress stimulates intracellular calcification by the coccolithophore Emiliania huxleyi (Haptophyceae) under phosphate-deficient conditions. Mar Biotechnol (NY) 11: 327-333

Schroeder D, Biggi G, Hall M, Davy J and others (2005) A genetic marker to separate Emiliania huxleyi (Prymnesiophyceae) morphotypes. J Phycol 41:874-879

Signorini S, Garcia VMT, Piola AR, Garcia CAE, Mata MM, McClain CR (2006) Seasonal and interannual variability of calcite in the vicinity of the Patagonian shelf break $\left(38^{\circ} \mathrm{S}-52^{\circ} \mathrm{S}\right)$. Geophys Res Lett 33:L16610. doi:10.1029/ 2006GL026592

Triantaphyllou M, Dimiz M, Krasakpoulou E, Malinverno E, Lianou V, Souvermezoglou E (2010) Seasonal variation in Emiliania huxleyi coccolith morphology and calcification in the Aegean Sea (eastern Mediterranean). Geobios 43:99-110

Tyrrell T, Merico A (2004) Emiliania huxleyi: bloom observations and the conditions that induce them. In: Thierstein HR, Young JR (eds) Coccolithophores: from molecular processes to global impact. Springer-Verlag, Heidelberg, p 75-97

Van Bleijswijk J, Kempers R, Veldhuis M, Westbroek P (1994) Cell and growth characteristics of types A and B of Emiliania huxleyi (Prymnesiophyceae) as determined by flow cytometry and chemical analyses. J Phycol 30:

Editorial responsibility: Katherine Richardson, Copenhagen, Denmark
$230-241$

- Watabe N, Wilbur K (1966) Effects of temperature on growth, calcification and coccolith formation in CocColithus huxleyi (Coccolithineae). Limnol Oceanogr 11: 567-575

Young JR (1993) The description and analysis of coccolith structure. Knihovnicha ZPN 1:35-71

Young JR (1994) Variation in Emiliania huxleyi coccolith morphology in samples from the Norwegian EHUX experiment, 1992. Sarsia 79:417-425

Young JR, Westbroek P (1991) Genotypic variation in the coccolithophorid species Emiliania huxleyi. Mar Micropaleontol 18:5-23

Young JR, Ziveri P (2000) Calculation of coccolith volume and its use in calibration of carbonate flux estimates. Deep-Sea Res II 47:1679-1700

Young JR, Geisen M, Cros L, Kleijne A, Sprengel C, Probert I, Østergaard JB (2003) A guide to extant calcareous nannoplankton taxonomy. J Nanno Res (Sp 1) :1-125

> Ziveri P, de Bernardi B, Baumann KH, Stoll H, Mortyn P (2007) Sinking of coccolith carbonate and potential contribution to organic carbon ballasting in the deep ocean. Deep-Sea Res II 54:659-675

Zondervan I (2007) The effects of light, macronutrients, trace metals and $\mathrm{CO}_{2}$ on the production of calcium carbonate and organic carbon in coccolithophoresA review. Deep-Sea Res II 54:521-537

Submitted: May 11, 2011; Accepted: October 10, 2011 Proofs received from author(s): November 28, 2011 